\title{
THE TEMPERATURE STRUCTURE OF A MID-LATITUDE, DIMICTIC LAKE DURING FREEZING, ICE COVER AND THAWING
}

\author{
W.H. Parrott and W.M. Fleming
}

November 1970

\author{
DA PROJECT 1T061101A91A \\ CORPS OF ENGINEERS, U.S. ARMY \\ COLD REGIONS RESEARCH AND ENGINEERING LABORATORY \\ HANOVER, NEW HAMPSHIRE
}




\section{PREFACE}

This report was prepared by Mr. W.H. Parrott, Research Physicist, Technical Services Division and Captain W. M. Fleming, U.S. Army, Research Geochemist, Snow and Ice Branch, Research Division, U.S. Army Cold Regions Research and Engineering Laboratory (USA CRREL). The report is published under DA Task 1T061101A91A.

The following USA CRREL personnel participated in the program. Mr. R. Guyer constructed the thermocouples and performed much of the electrical work in the data acquisition system and the automatic wind and radiation recorders. Mr. R.T. Atkins solved other circuit problems on the data acquisition system. Mr. G.E. Fellers prepared the computer programs for data reduction. SP5 C.A. Wolf analyzed water samples for conducting determinations in the USA CRREL aqueous chemistry laboratory.

Drs. N.M. Johns on and G.L. Likens, Dartmouth College, designed the thermistor probe used in measurement of temperatures in the bottom sediments, assisted with the loan of other equipment, and made many helpful suggestions. Mr. R.W. Morse, Dartmouth College, performed cation analyses.

The authors wish to express appreciation to Dr. C.C. Langway, Jr., USA CRREL, for his guidance and constructive criticism throughout this study; and to Mr. M.A. Bilello and Mr. S.L. Dingman, USA CRREL, and Dr. J.B. Lyons, Dartmouth College, for their helpful reviews. The report was technically reviewed by Dr. Langway.

The contents of this report are not to be used for advertising, publication or promotional purposes. Citation of trade names does not constitute an official endorsement or approval of the use of such commercial products.

Manuscript received 15 May 1970 


\section{CONTENTS}

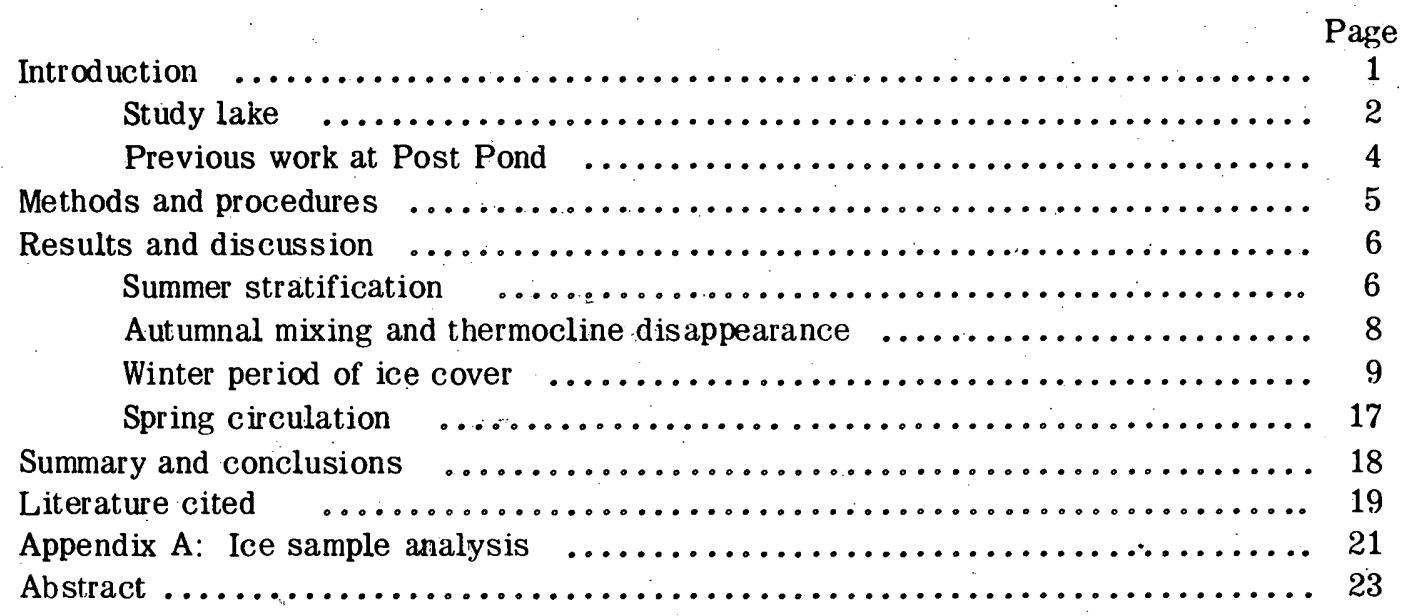

\section{ILLUSTRATIONS}

Figure

1. Location and watershed of Post Pond $\quad \ldots \ldots \ldots \ldots \ldots \ldots \ldots \ldots \ldots$

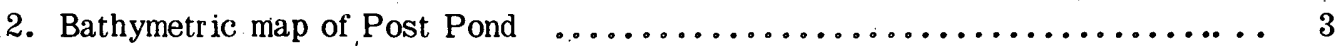

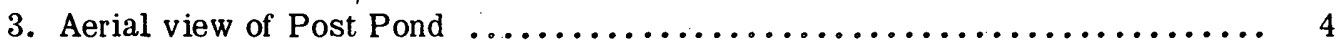

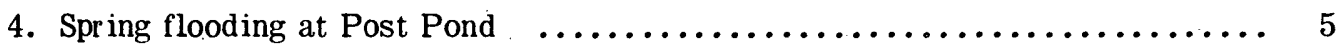

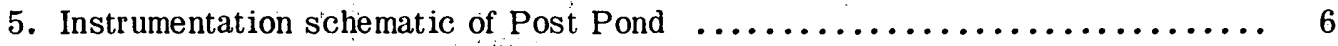

6. Late summer and aútumn temperature profiles, $1968 \ldots \ldots \ldots \ldots \ldots \ldots \ldots \ldots$

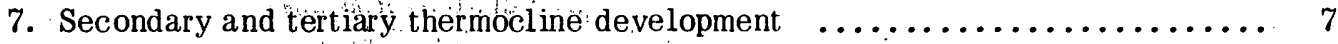

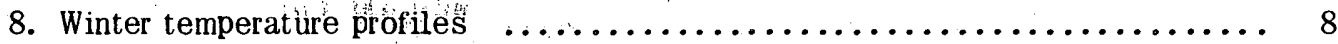

9. Depth of ice and water vis percentage of light penetration $\ldots \ldots \ldots \ldots \ldots \ldots 10$

10. Temperature profile on 13 March $1969 \quad \ldots \ldots \ldots \ldots \ldots \ldots \ldots \ldots . . . \ldots$

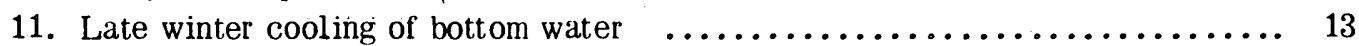

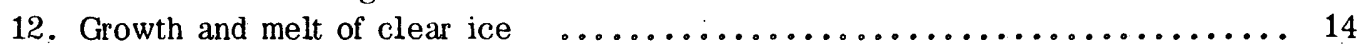

13. Initial melting and moat formation around shoreline in spring $\ldots \ldots \ldots \ldots \ldots . . \ldots 14$

14. Candling of thin ice cover during spring melting $\ldots \ldots \ldots \ldots \ldots \ldots \ldots \ldots . \ldots \ldots$

15. Thermal instability and conductivity during melt season $\ldots \ldots \ldots \ldots \ldots \ldots \ldots$

16. Effect of temperature and dissolved solids on density, 18 April $\ldots \ldots \ldots \ldots \ldots 16$

17. Spring circulation and thermocline development $\ldots \ldots \ldots \ldots \ldots \ldots \ldots$

\section{TABLES}

Table

I. Cation analyses, $18 \mathrm{April} 1969(\mathrm{mg} / \mathrm{liter}) \ldots \ldots \ldots \ldots \ldots \ldots \ldots \ldots \ldots \ldots \ldots$ 


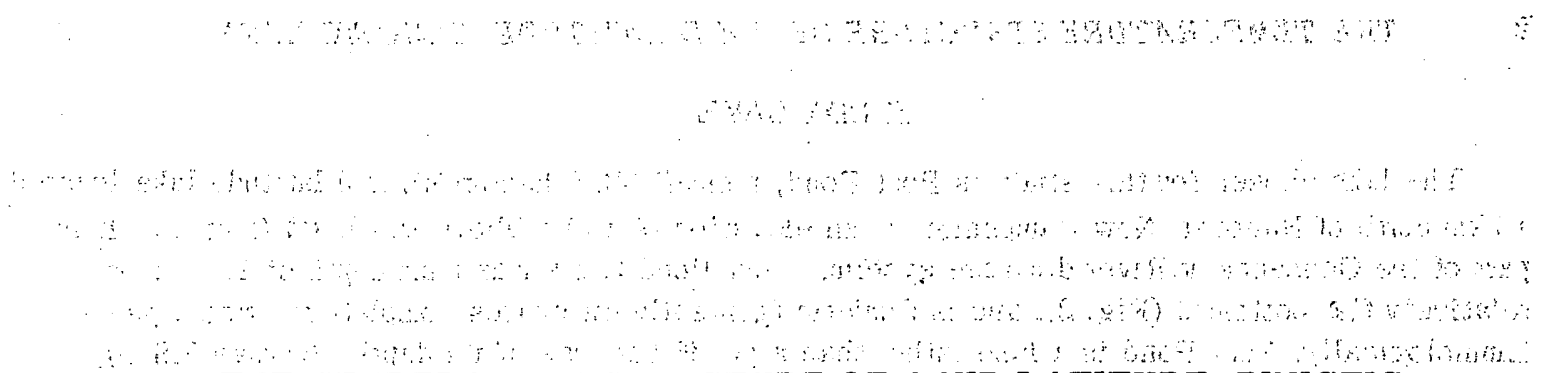

THE TEMPERATURE STRUCTURE OF A MID-LATITUDE, DIMICTIC LAKE DURING FREEZING, ICE COVER, AND THAWING

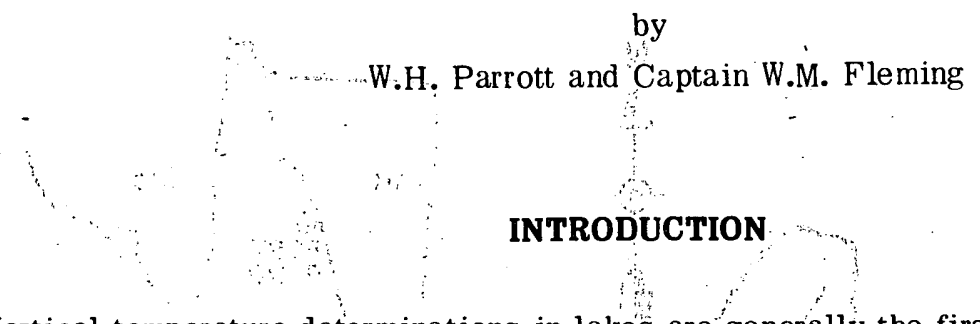

Vertical temperature determinations in lakes are generally the first and most basic measurements of any limnologic study. The first series of vertical temperature profiles was made on Scottish lakes by Jardine during 1812-1814 (Hutchinson, 1957):. Thoreau was the first Àmerican to write about thermal stratification when he lived at Walden Pond in the 1800 's, but he did not take enough readings to perceive the shape of the thermal curve (Deevey, 1942). The work of Birge $(1910,1915)$ from 1895 to 1935 on. Wisconsin lakes marked the real beginning of limnologic studies (including temperature measurements) in the United States.

Although the temperature profiles of many of the world's temperate lakes were generally described in the last century, few investigators have made continuous ànd detailed measurements of the thermal profile, especially during the critical times of freezing and thawing. The logistical problems associated with temperature measurements while an inial ice cover is forming and while it is melting are important reasons for neglecting this area of limnological research. The major objective of this research is to describe the thermal relationships at the se critical times.

Continuous water temperature measurements were made in a shallow lake in Michigan (Bilello, 1968) during ice formation, growth, and decay, but the $2-\mathrm{m}$ lake depth precluded the development of a classical three-layered stratification. Other investigators périodically (at weekly or longer intervals) obtained water temperature profiles and calculated the annual heat budget for a lake (Birge, 1915; Hutchinson, 1937; Añderson, 1964; and many others).

Many analytical techniques have been proposed for calculating or estimating water temperature profiles for various meteorological conditions. Some investigators concentrated on the exchange of heat across the air/water interface (Edinger et.al., 1968; Dutton and Bryson, 1962), while others developed theories for the vertical development of the thermocline over time in a, deep lake (Dake and Harleman, 1969). Important parameters of heat loss in the overall budget, such as nocturnal radiation loss and its effect on convection and thermocline development, were studied by Anderson (1968). However, few theoretical studies have been ver if ied by actual continuous measurements of lake temperatures.

During the course of this lake study, temperatures were collected at 24 data points in the lake every hour on the hour over an approximately two-year period. This resulted in a very large popuiation of data. Obviously not all of these data were analyzed or reported here. However, all of the data are available in the CRREL library to the CRREL scientif ic staff or outside members of the scientific community for further analysis. 


\section{STUDY LAKE}

The lake chosen for this study is Post Pond, a small (46.6 hectares), mid-latitude lake located $18 \mathrm{~km}$ north of Hanover, New Hampshire, at an elevation of $130 \mathrm{~m}$ above sea level (Fig. 1). It is part of the Connecticut River drainage system. Post Pond has a maximum depth of $11.7 \mathrm{~m}$, is relatively flat bottomed (Fig. 2), and is dimictic (generally circulates completely twice a year). Limnologically, Post Pond is a lake rather than a pond* because of its depth (average $6.8 \mathrm{~m}$ ), small littoral zone, and pronounced three-layered thermal stratification.

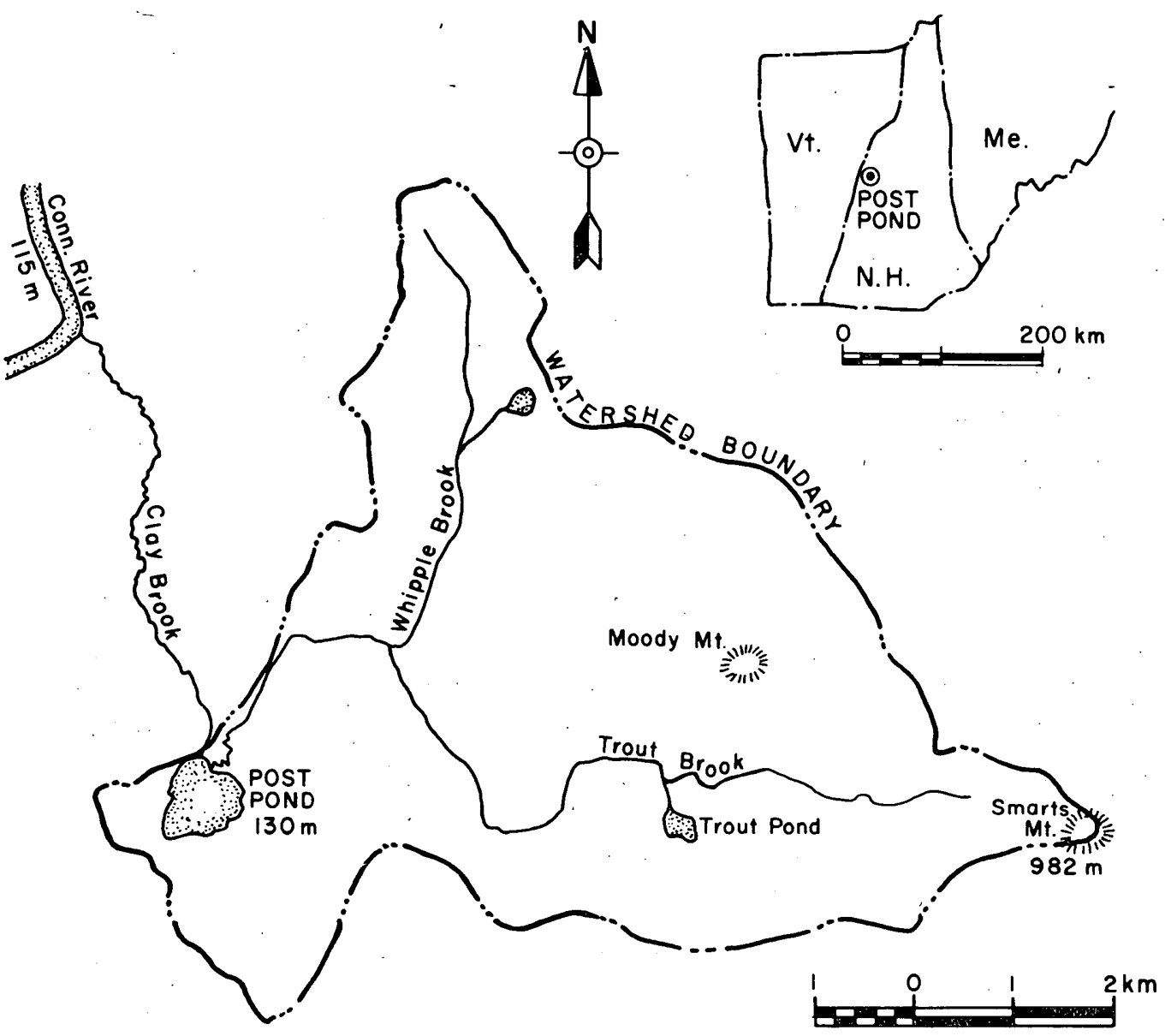

Figure 1. Location (above) and watershed of Post Pond.

\section{Origin and structure}

Post Pond is glacial in origin and occupies a bas in that was probably a large kettle. On two sides of the lake is an irregular, glacially scoured landscape consisting of hills with a maximum relief of $288 \mathrm{~m}$. The hills are composed of early Paleozoic metasediments (Post Pond is a volcanic member of the Orfordville formation) and are covered thinly with glacial till, although bedrock outcrops on ridge crests. On the south is a smaller ridge of glacially scoured bedrock and morainal debris, while on the north lies a swampy lowland in which both inlet (Trout. Brook) and outlet. (Clay Brook) are located. Clay Brook is incised by glacial clays and silts, indicat ing the' former presence of a larger glacial lake.

* A pond is defined by Reid (1961) as a small body of standing watér shallow enough to have rooted plints growing across it. 


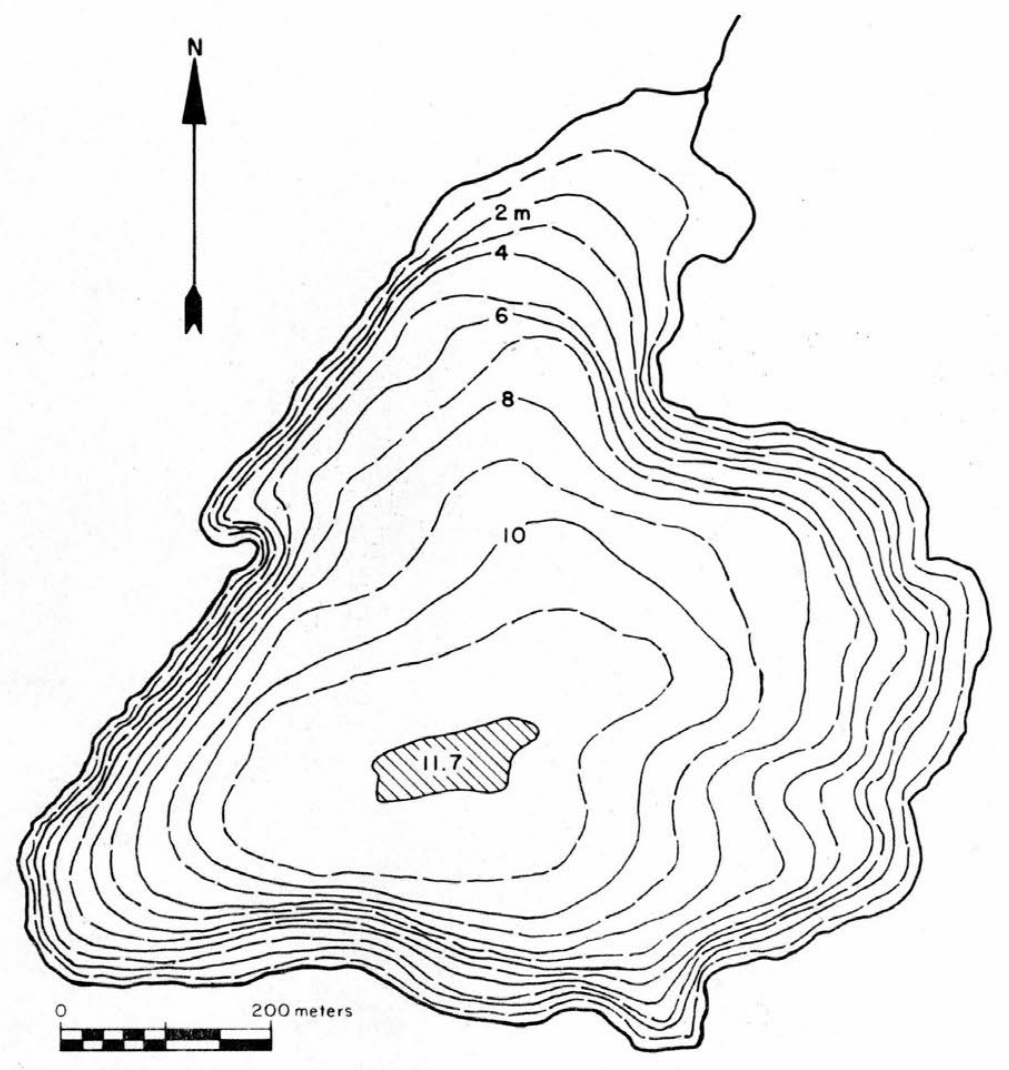

Figure 2. Bathymetric map of Post Pond. Contour interval $=1 \mathrm{~m}$.

\section{Climate and hydrology}

The climate of the upper Connecticut Valley is classified as humid continental with short, cool summers and long, cold winters (Trewartha, 1954). Sudden and rapid changes in the weather, a large daily and annual range of temperature, and an equable yearly precipitation distribution are characteristics of this climate. According to the climatological records of the Environmental Science Services Administration - Weather Bureau (1966), the average July temperature for Hanover is $20.6^{\circ} \mathrm{C}$, and the average January temperature is $-6.9^{\circ} \mathrm{C}$. The average yearly temperature is $7.4^{\circ} \mathrm{C}$. Annual precipitation is about $94 \mathrm{~cm}$, one-quarter to one-third of which is snow.

The lake drains a watershed of $36.1 \mathrm{~km}^{2}$ which extends to the east and north of the lake (Fig. 1). The major inlet stream (Trout Brook) supplies an estimated $90 \%$ of the available runoff water for the lake, and originates near Smarts Mountain (982-m elevation) at the eastern boundary of the watershed. The outlet stream (Clay Brook) is near the inlet stream on the north side of the lake (Fig. 3), and flows northwest for $5 \mathrm{~km}$ into the Connecticut River. Discharge measurements made at low flow periods in the fall of 1968 with a Gurley Current Meter showed that the inlet discharge $\left(0.03 \mathrm{~m}^{3} / \mathrm{sec}\right)$ was more than twice the outlet discharge. Flooding occurs yearly in April due to spring snowmelt (Fig. 4), and Trout Brook flows at an estimated 10 to 15 times its average discharge at that time. 


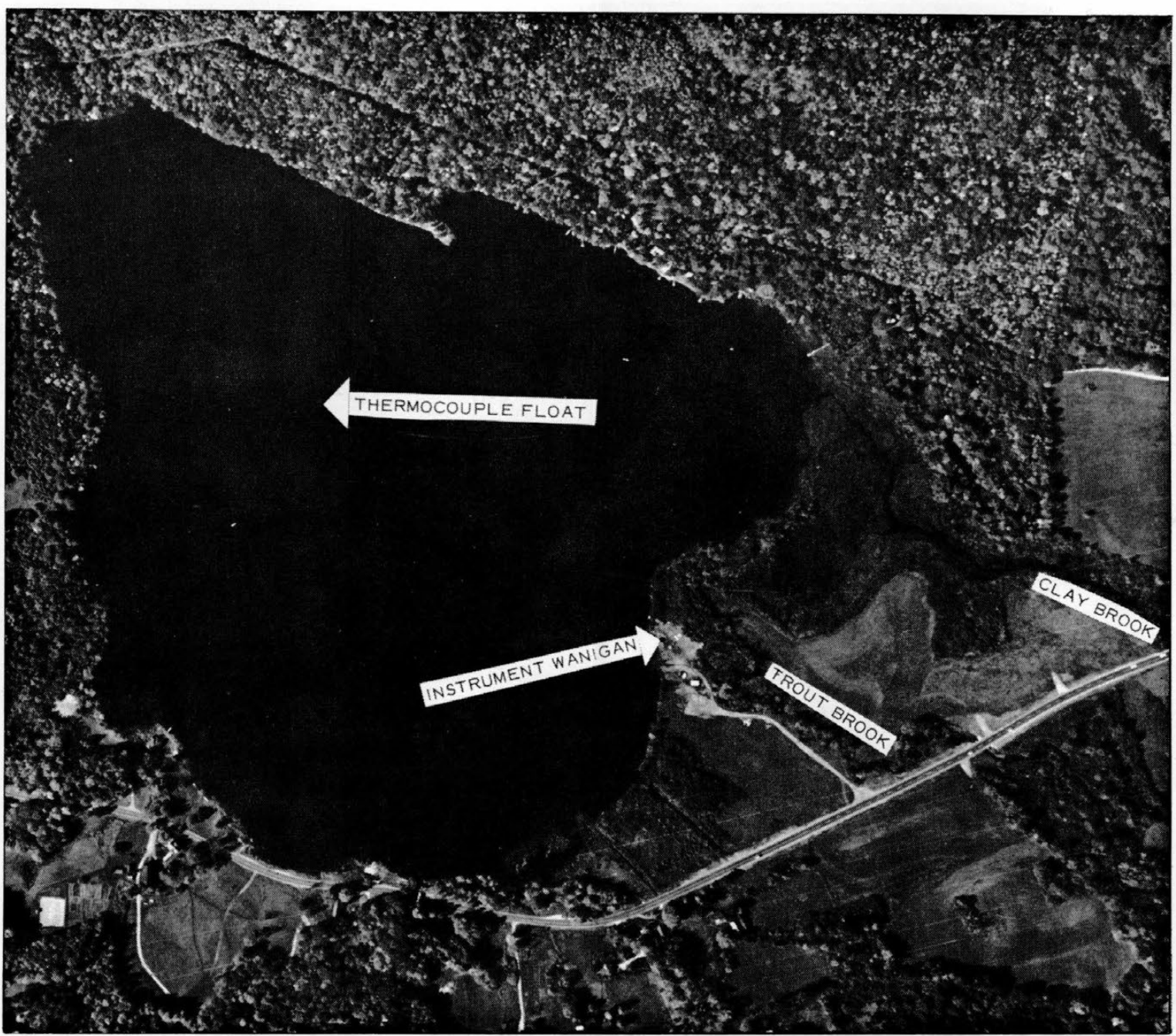

Figure 3. Aerial view of Post Pond.

Local groundwater levels around the lake are high (within $1.5 \mathrm{~m}$ of the ground surface) and fluctuate with spring snowmelt and heavy rains. Shallow groundwater aquifers probably account for a significant amount of the subsurface inflow to the lake. Local groundwater seepage into the lake can occur during the winter since the snow covered soils remain essentially unfrozen (Likens et al., 1967). The contribution of deep springs to the hydrology of the lake is unknown.

An investigation of the ice texture, ice structure, and growth rate of lake ice on Post Pond was made during the winter of 1956-57 (Ragle, 1963).

\section{Organic productivity}

The lake has a relatively high rate of organic productivity and can be termed mildly eutroplric: by New Hampshire standards according to Likens (personal communication, 1968). Many species of fish are present; among the more abundant are brook trout, rainbow trout, smallmouth bass, rock bass, yellow perch, and pickerel. 


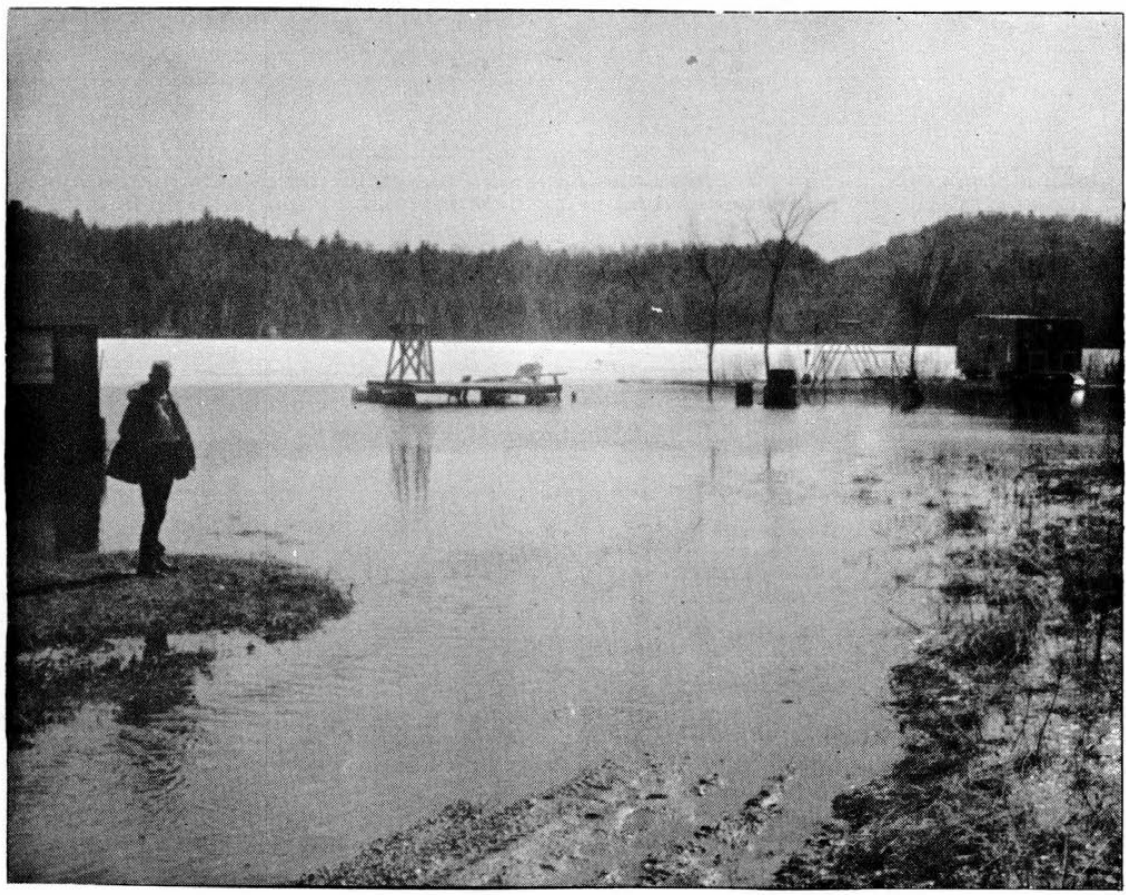

Figure 4. Spring flooding at Post Pond.

\section{METHODS AND PROCEDURES}

The lake was instrumented over its maximum depth $(11.7 \mathrm{~m})$ with a string of 24 thermocouples (Fig. 5). The vertical spacing of the thermocouples is presented in Figure 7. The thermocouples were anchored in the bottom sediments, attached to a nylon line, and positioned at the surface of the lake by a Styrofoam spar float. The top six thermocouples were spaced with respect to the surface of the lake, and the lower eighteen thermocouples were spaced with respect to the bottom of the lake. One thermocouple was emplaced $25 \mathrm{~cm}$ into the bottom sediments at the end of a cone-shaped anchor. The lead wire extended along the lake bottom and terminated at the instrument wanigan located on the shore. In addition, continuous air temperatures and water temperatures of the incoming stream were recorded. Temperature measurements were accurate to $\pm 0.1^{\circ} \mathrm{C}$.

Temperature information was collected from the thermocouples by an automatic data acquisition system (Model 2010D Dymec) with a paper punch tape output. The major components were a digital voltmeter and a Joseph Kaye Reference Junction. During the first portion of the season a $0^{\circ} \mathrm{C}$ temperature reference junction was used, but as the lake approached freezing the signal diminished and a $150^{\circ} \mathrm{C}$ reference junction was substituted. To obtain diurnal detail, a 1-hour sampling interval was used. A computer program was designed to convert the paper punch tape data recorded in millivolts to temperature in degrees Celsius.

Other meteorological parameters continuously recorded included: wind direction and velocity (Scientific Associates Anemometer No. 470), incoming shortwave solar radiation (Kahl Radiometer No. $28 \mathrm{AM}$ 100), and net all-wave solar radiation (Kahl Radiometer No. 29 AM 100) over the lake surface. Infrequent observations and measurements included: precipitation, relative humidity, water level fluctuations of the lake, snow depth, snow density, and ice thickness. 


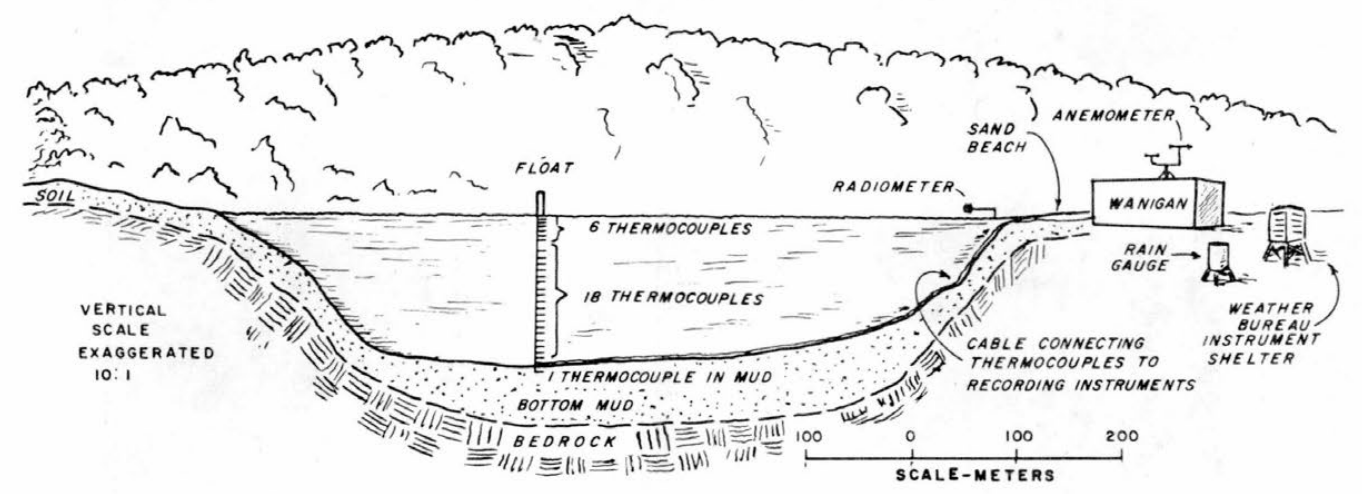

Figure 5. Instrumentation schematic of Post Pond.

Temperature measurements within the bottom sediments were measured with a thermistor probe (designed by Likens and Johnson, 1969). The thermistor was read with a modified Wheatstone bridge which gave an accuracy within $\pm 0.1^{\circ} \mathrm{C}$.

Water samples were taken with a nonmetallic water sampling bottle during various regimes throughout the season. Conductivity and cation analyses were made in the CRREL aqueous chemistry laboratory.

Samples of winter ice were collected for crystallographic analysis. A Whitney Underwater Daylight Meter was used to measure the transmission of solar radiation through the water.

\section{RESULTS AND DISCUSSION}

Post Pond has three pronounced thermal layers at the time of summer stratification. The upper layer of more or less uniformly warm, circulating, and sometimes turbulent water is termed the epilimnion (Hutchinson, 1957). The lower layer, deep, cold and relatively undisturbed, is called the hypolimnion (Birge, 1910). In between is a region of rapid decrease in temperature, commonly known as the metalimnion or thermocline. Hutchinson defined the thermocline as the zone of maximum rate of decrease in temperature. Convective mixing between the epilimnion and hypolimnion is essentially nonexistent. At times of spring and autumn overturn (circulation) the lake mixes completely. Therefore, during summer and autumn when the lake is stratified, the thermocline acts as a barrier to mixing between upper (epilimnion) and lower (hypolimnion) water.

\section{Summer stratification}

Hourly readings of lake temperature began on 27 August 1968, when the lake was well stratified and in a condition of extreme thermal stability (Fig. 6). The epilimnion was isothermal at $20.6^{\circ} \mathrm{C}$ to a depth of $4.5 \mathrm{~m}$. As average daily air temperatures gradually decreased, the epilimnion deepened to $5.1 \mathrm{~m}$ at an isothermal temperature of $18.4^{\circ} \mathrm{C}$ on 15 September.

Secondary and tertiary thermocline development in the epilimnion. On 16 September a warming period began that lasted approximately 15 days and resulted in the development of secondary and tertiary thermoclines in the epilimnion. The warming period was started by clear skies and little wind, combined with increased air temperatures.

The differences in the temperature profiles of the epilimnion between 15 September and 21 September are striking (Fig. 7). On 15 September the entire epilimnion was isothermal at $18.4^{\circ} \mathrm{C}$, and the temperature curve was classical, with one primary thermocline extending from the base of 


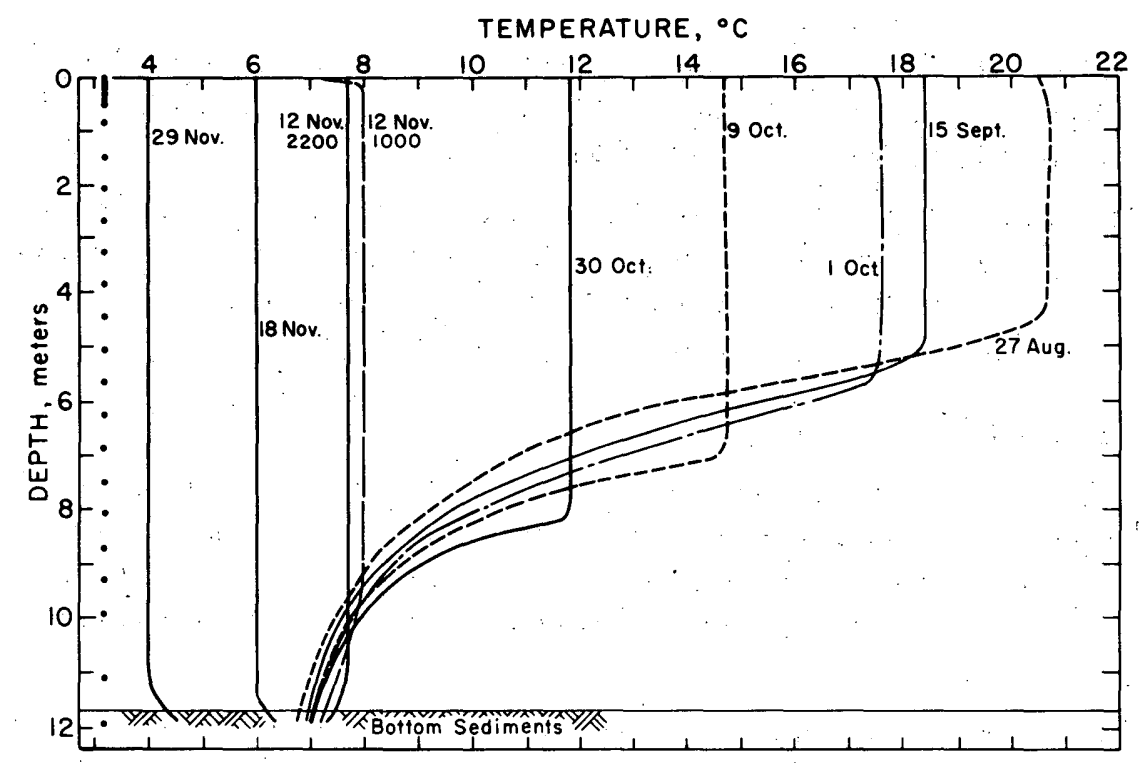

Figure 6. Late summer and autumn temperature profiles, 1968.

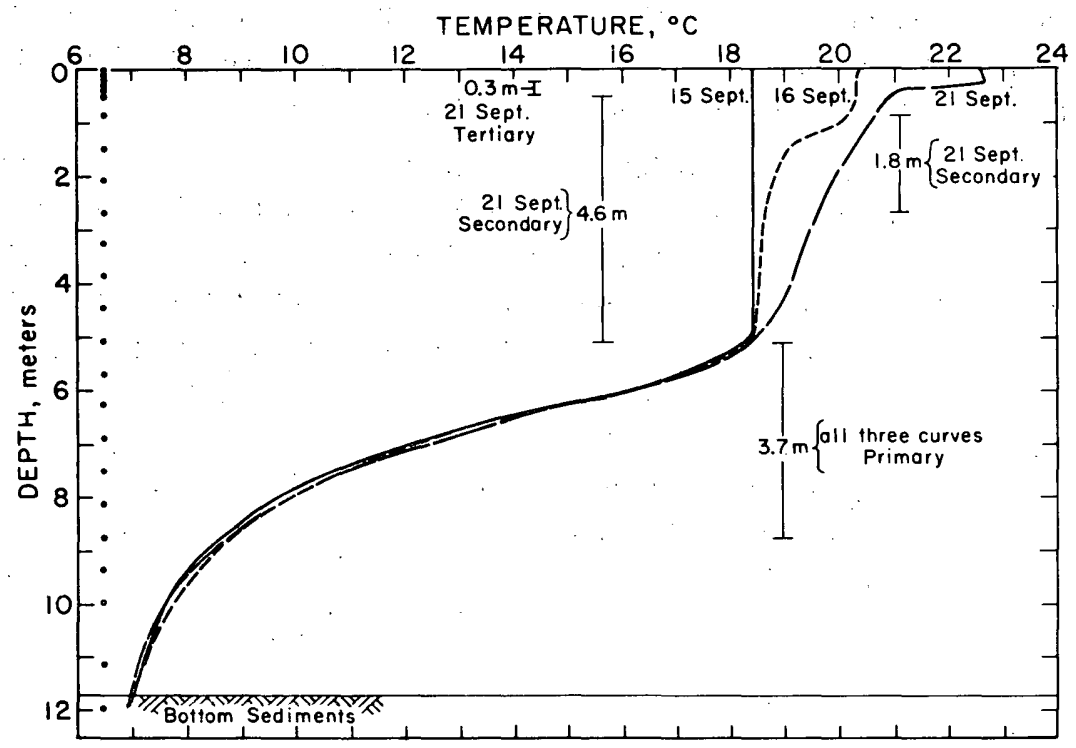

Figure 7. Secondary and tertiary thermocline development.

the epilimnion $(5.1 \mathrm{~m})$ to the top of the hypolimnion $(8.7 \mathrm{~m})$. The primary thermocline exhibited a rate of temperature decrease of $2.7^{\circ} \mathrm{C} / \mathrm{m}$. The primary thermocline was completely unaffected by subsequent changes in the epilimnion in the following 6 days.

Warm air temperatures and negligible wind on 16 September resulted in the development of a secondary thermocline in the epilimnion, which extended from $0.8 \mathrm{~m}$ to $2.7 \mathrm{~m}$ (Fig. 7) and showed a rate of temperature decrease of $0.8^{\circ} \mathrm{C} / \mathrm{m}$. The primary thermocline was identical to the one described for 15 September.

Continued high air temperatures combined with clear skies and little wind resulted in the development of a tertiary thermocline on 21 September (Fig. 7). This small thermocline extended 
from $0.2 \mathrm{~m}$ to $0.5 \mathrm{~m}$ and exhibited a rate of temperature decrease of $6.0^{\circ} \mathrm{C} / \mathrm{m}$. A secondary thermocline that extended from $0.5 \mathrm{~m}$ to $5.1 \mathrm{~m}$ and showed a rate of temperature decrease $0.5^{\circ} \mathrm{C} / \mathrm{m}$ was also present. Again, the primary thermocline was identical to the one of the previous 6 days.

End of the summer stratification period. The warming period ended on 1 October, and the secondary and tertiary thermoclines disappeared as colder air temperatures and wind mixed the entire epilimnion isothermally at $17.6^{\circ} \mathrm{C}$ to a depth of $5.7 \mathrm{~m}$ (Fig. 6). This date can be termed the end of the summer stratification period and the beginning of autumnal mixing.

\section{Autumnal mixing and thermocline disappearance}

Continued deepening of the primary thermocline. Cool air temperatures and wind enabled the thermal mixing process to cool the epilimnion gradually and to deepen the thermocline after 1 October. By 9 October the top of the thermocline was at $6.9 \mathrm{~m}$ with the epilimnion isothermal at $14.7^{\circ} \mathrm{C}$ (Fig. 6). On 30 October the thermocline deepened to $8.1 \mathrm{~m}$ with an isothermal epilimnion at $11.8^{\circ} \mathrm{C}$.

The thermocline was at a depth of $9.3 \mathrm{~m}$ on 8 November (with an isothermal epilimnion of $9.4^{\circ} \mathrm{C}$ ), and by 12 November at 1000 hours was at $9.9 \mathrm{~m}$ (with an isothermal epilimnion of $8.0^{\circ} \mathrm{C}$ ).

Autumn overturn. The autumn overturn is defined as the time during which complete mixing occurs throughout the entire vertical pr of ile of the lake. The overturn period began at Post Pond on 12 November at 2200 hours when the entire lake became is othermal at $7.7^{\circ} \mathrm{C}$. The water was all at the same density and therefore extremely vulnerable to mixing.

As air temperatures decreased, the lake cooled isothermally to $7.0^{\circ} \mathrm{C}$ on 14 November, to $6.0^{\circ} \mathrm{C}$ on 18 November, to $5.0^{\circ} \mathrm{C}$ on 23 November, and to $4.0^{\circ} \mathrm{C}$ (temperature of maximum density) on 29 November (Fig. 6). During this time of isothermal cooling winds were light, but quite sufficient to mix the lake completely. Often the top $0.5 \mathrm{~m}$ of the lake cooled $0.5^{\circ} \mathrm{C}$ more than the underlying $11.2 \mathrm{~m}$, but within 8 hours light winds were sufficient to mix the lake and cool the entire $12-\mathrm{m}$ column.

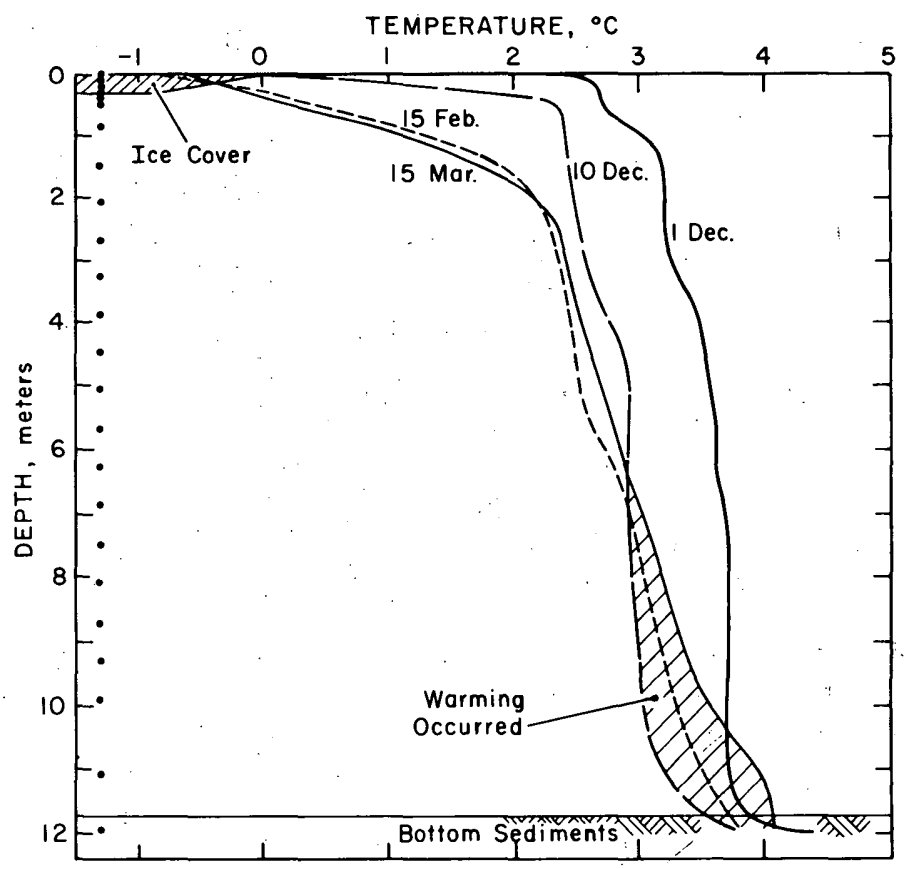

Figure 8. Winter temperature profilés. 
Reverse stratification was evident on 1 December, with the upper $0.5 \mathrm{~m}$ colder than $3^{\circ} \mathrm{C}$ and the bottom remaining at $3.7^{\circ} \mathrm{C}$ (Fig. 8). By 6 December light winds were sufficient to circulate the lake for the last time and mix it completely to $3.2^{\circ} \mathrm{C}$. Calm conditions and freezing air temperatures led to the development of permanent reverse stratification on 7 December, signifying the end of the autumn overturn. The overturn had lasted from 12 November to 7 December - a total of 25 days. An important cause of the long overturn period was the absence of storms or strong winds, which, if present, could have combined with cold air temperatures to bring the lake to $4^{\circ} \mathrm{C}$ in a few days.

\section{Winter period of ice cover}

Establishment of ice cover. On the night of 8 December calm, cold conditions led to the formation of an initial ice skim which melted the following day. Similar conditions the following night led to the initiation of a permanent ice cover. Rapid growth of clear ice resulted in a cover approximately $4 \mathrm{~cm}$ thick the following day. The resulting inverse stratification on 10 December intensified (Fig. 8).

Ice covered period - cooling of the water mass. The ice cover lasted from 10 December 1968 to 19 April 1969 (130 days, or 36\% of a year). During this time the ice cover thickened to a maximum of $62 \mathrm{~cm}$ on 7 March ( $42 \mathrm{~cm}$ of clear ice, $20 \mathrm{~cm}$ of snow-ice*), but the temperature structure of the water changed only slightly. During March 1968, ice samples were taken from six sites on the pond. Some of these data are presented in Appendix A. The difference between the snow-ice and the clear ice is quite discernible. Profiles from the four months of ice cover show that the upper $7 \mathrm{~m}$ cooled slightly while the lower $5 \mathrm{~m}$ warmed slightly (Fig. 8).

Ice covered period - heat from bottom sediments. Slow warming of the lower $5 \mathrm{~m}$ of water was evident (see Fig. 8). By 15 February the lower part of the hypolimnion had warmed to $3.5^{\circ} \mathrm{C}$ (from $3.2^{\circ} \mathrm{C}$ on 10 December); on 5 March it had warmed to $3.8^{\circ} \mathrm{C}$; and by $15 \mathrm{March}$ it had warmed to $4.0^{\circ} \mathrm{C}$. This heat was furnished to the lake from bottom sediments in the form of solar heat stored during the summer months, to be released to the water during the period of ice cover. Although a small amount of visible solar radiation may penetrate $2 \mathrm{~m}$ of lake ice and affect ice growth at the ice/water interface (Swinzow, 1966), no infrared radiation can be expected to penetrate.

Results with a Whitney Underwater Daylight Meter on 8 January (with a 38-cm ice cover) showed that approximately $10 \%$ of total surface light penetrated $1 \mathrm{~m}$ of ice and water, while only about $0.1 \%$ penetrated $5 \mathrm{~m}$ (see Fig. 9). In addition, the ice was continually shielded from solar radiation by a substantial snow cover (average depth $25 \mathrm{~cm}$ ) from 22 December to $18 \mathrm{March}$. This reduced the penetration more.

Thermal gradients in bottom sediments were significant portions of the total heat budget of lakes according to Johns on and Likens (1967) and Likens and Ragotzkie (1965). Studies of Likens and Johnson (1969) showed that the bottom sediments of two small Wisconsin lakes contributed $10-12 \%$ of the total annual heat budgets.

Thermal gradients were measured on 13 March (approximately the time of maximum ice thickness) to a depth of $9 \mathrm{~m}$ in the sediments (Fig. 10). An average thermal gradient of about $0.5^{\circ} \mathrm{C} / \mathrm{m}$ was found for the upper $3 \mathrm{~m}$ of sediments and a steady-state thermal gradient of about $0.07^{\circ} \mathrm{C} / \mathrm{m}$

* Snow-ice is a frozen slush layer that forms over the clear ice from a mixture of snow and lake water. The accumulating load of fallen snow causes the clear ice to fracture; water ascends through the fracture pattern, mixes with the snow, and freezes. The contact between clear ice and snow-ice is easily dis. cernible (see App A). 
10

THE TEMPERATURE STRUCTURE OF A MID-LATITUDE, DIMICTIC LAKE

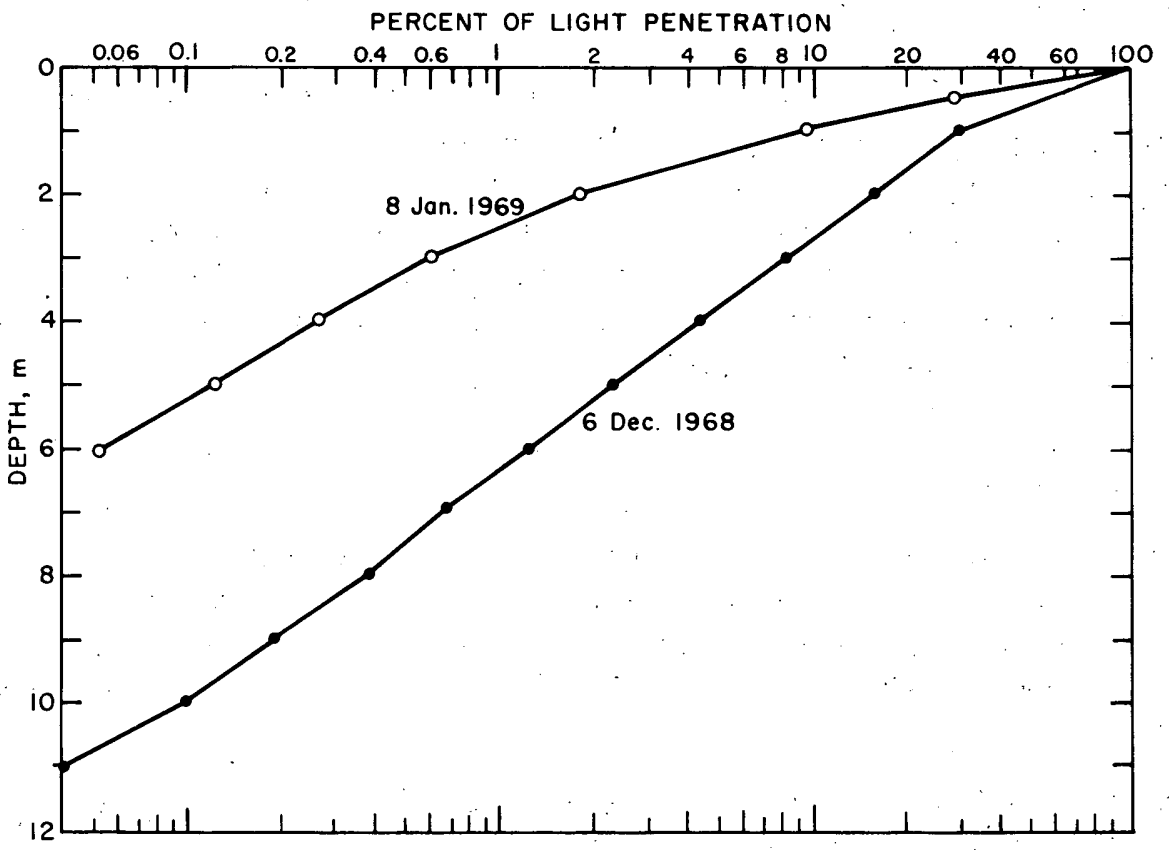

Figure 9. Depth of ice and water vs percentage of light penetration.

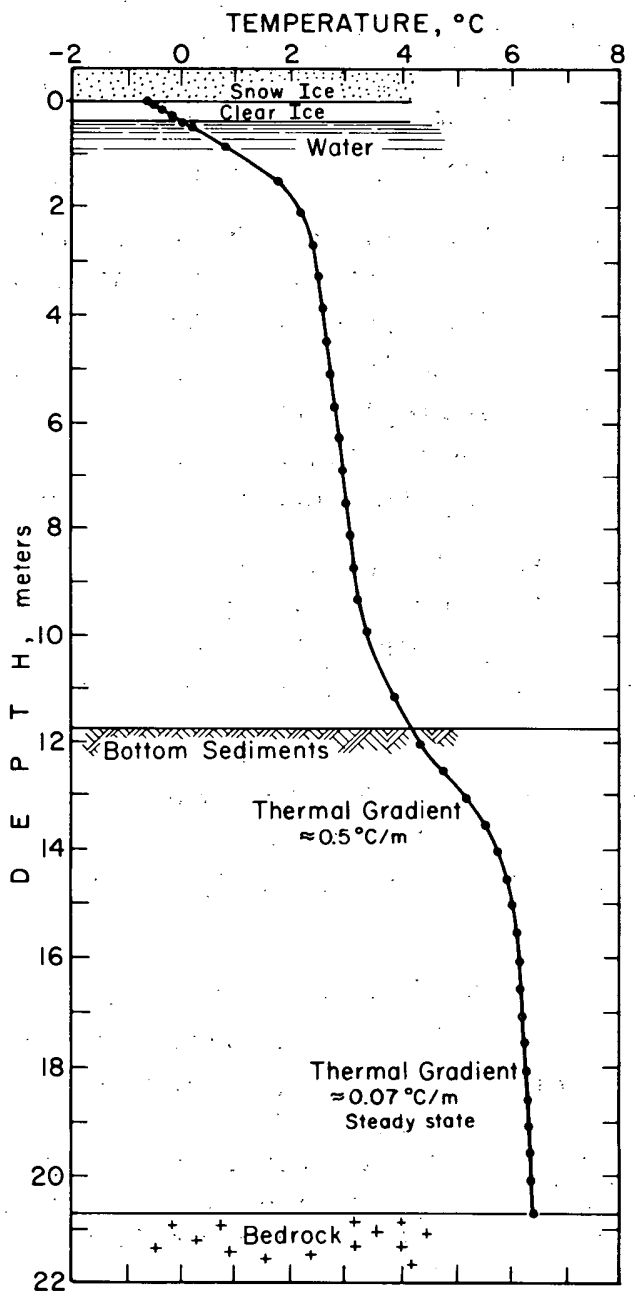

Figure 10. Temperature profile on 13 March 1969. 
was found for the underlying $6 \mathrm{~m}$. The steady-state thermal gradient is in part a measure of the terrestrial geothermal gradient, and other studies have calculated that the geothermal gradient accounts for about half of the steady-state gradient measured in lake sediments (Johnson and Likens, 1967). A steady-state thermal gradient of $0.20^{\circ} \mathrm{C} / \mathrm{m}$ was measured in the bottom sediments of a small Wisconsin lake (Likens and Johnson, 1969); this is approximately three times the gradient measured for the sediments of Post Pond.

Considering only the larger thermal gradient of $0.5^{\circ} \mathrm{C} / \mathrm{m}$ in the upper $3 \mathrm{~m}$ of sediments, the heat flux through the sediments to the water can be calculated according to the general heat conduction equation:

$$
\Phi=k \Delta \frac{T}{L}
$$

where:

$$
\begin{aligned}
\Phi & =\text { heat flux through sediments }\left(\mathrm{cal} / \mathrm{cm}^{2} \text { day }\right) \\
k & =\text { thermal conductivity of sediments }\left(\mathrm{cal} \mathrm{cm} / \mathrm{cm}^{2} \mathrm{sec}^{\circ} \mathrm{C}\right) \\
\Delta \frac{T}{L} & =\text { average thermal gradient in sediments }\left({ }^{\circ} \mathrm{C} / \mathrm{cm}\right) .
\end{aligned}
$$

Since the bottom sediments of Post Pond are similar to those of Tub Lake, Wiscons in, a similar thermal conductivity $\left(1.36 \times 10^{-3} \mathrm{cal} \mathrm{cm} / \mathrm{cm}^{2} \sec ^{\circ} \mathrm{C}\right)$ is assumed (Likens and Johnson, 1969; McGaw, in prep). Thus, the heat flux conducted through the upper $3 \mathrm{~m}$ of sediments into Post Pond during maximum ice cover was $-6.8 \times 10^{-6} \mathrm{cal} / \mathrm{cm}^{2} \mathrm{sec}$ or $-0.59 \mathrm{cal} / \mathrm{cm}^{2}$ day.

The amount of heat conducted into the lower $5 \mathrm{~m}$ of water is enough to account for the gradual increase in heat content. The amount of heat introduced during the period 10 December to $15 \mathrm{March}$ is calculated according to:

$$
Q_{\mathrm{w}}=\sum_{D_{1}}^{D_{2}}\left(T_{\mathrm{t} 1}-T_{\mathrm{t} 2}\right)(\Delta h)\left(f_{\mathrm{w}}\right)\left(\rho c_{\mathrm{p}}\right)
$$

where:

$$
\begin{aligned}
Q_{\mathrm{w}} & =\text { heat content of the water, cal } / \mathrm{cm}^{2} \\
D_{1} & =\text { depth of } 6.7 \mathrm{~m} \\
D_{2} & =\text { depth of } 11.7 \mathrm{~m} \\
T_{\mathrm{t} 1} & =\text { water temperature on } 10 \mathrm{Dec}_{\mathrm{s}}{ }^{\circ} \mathrm{C} \\
T_{\mathrm{t} 2} & =\text { water temper ature on } 15 \mathrm{Mar},{ }^{\circ} \mathrm{C} \\
\Delta h^{\prime} & =\text { thickness of water layer at each depth interval, } \mathrm{cm} \\
f_{\mathrm{w}} & =\text { weighting factor from hypsographic curve for relative area at each depth } \\
c_{\mathrm{p}} & =\text { specific heat capacity of water, cal } / \mathrm{g}^{\circ} \mathrm{C} \\
\rho & =\text { density of water, } \mathrm{g} / \mathrm{cm}^{3} .
\end{aligned}
$$

Thus, the amount of heat gained by the lower $5 \mathrm{~m}$ of water during this period was approximately $51.5 \mathrm{cal} / \mathrm{cm}^{2}$.

The amount of heat conducted from the bottom sediments during the period 10 December to 15 March is calculated according to:

$$
Q_{\mathbf{s}}=\Phi \Delta t
$$


where:

$Q_{\mathrm{s}}=$ heat flux in upper $3 \mathrm{~m}$ of sediments, cal $/ \mathrm{cm}^{2}$

$\Phi=$ heat flux through sediments, $\mathrm{cal} / \mathrm{cm}^{2}$ day

$\Delta t=$ ice covered period, in days.

The heat flux in the sediments near the end of the ice-covered period $\left(-0.59 \mathrm{cal} / \mathrm{cm}^{2}\right.$ day on $13 \mathrm{March}$ ) is used, as it represents a smaller gradient than would be expected at the beginning of the winter (Likens and Johnson, 1969), and thus is a conservative measure of the heat available from the sediments:

$$
Q_{\mathrm{S}}=(-0.59)(96)=-56.6 \mathrm{cal} / \mathrm{cm}^{2} \text {. }
$$

The nearly equal values of $Q_{\mathrm{w}}$ and $Q_{\mathrm{S}}$ support the probability that heat from bottom sediments is enough to account for warming the water mass during ice cover. These results support Bilello's (1968) conclusion that bottom muds constitute the major heat source during ice cover. These results suggest that little heat was advected into Post Pond by deep groundwater sources during the winter.

These results must be interpreted as having validity only for the sediments in the deepest part of the lake, as Likens and Johns on (1969) show that sediments near the shoreline of lakes are thermally much more active.

Takagi's (1970) use of spline functions to analyze the temperatures observed in a lake enabled us to detect the period during which only vertical heat conduction was the mechanism of heat transfer. If the scatter ing due to observation errors is disregarded, a quantity called "the integral residual" becomes a minimum in this period. The standard deviation of the temperature observation can be found from the scattering. Only the differential equation is needed in this computation; none of the boundary and initial conditions are required.

Ice covered period - late winter cooling of bottom water. After warming gradually to $4.0^{\circ} \mathrm{C}$, the bottom $2 \mathrm{~m}$ of water cooled suddenly. (within 24 hours) to $3.1^{\circ} \mathrm{C}$ on 21 March (Fig. 11). Although it occurred at all depths, a similar spring cooling period was reported by Bilello (1968). The bottom water cooled further to $2.9^{\circ} \mathrm{C}$ on $24 \mathrm{March}$, and remained at that temperature until $27 \mathrm{March}$ when it began to warm. By 29 March the water was at $3.4^{\circ} \mathrm{C}$ and warmed gradually to $3.7^{\circ} \mathrm{C}$ on 9 April. The short cooling period lasted about 6 days (21 March to 27 March). Two possible explanations are offered: 1) the bottom sediments became thermally drained, thus causing the bottom water to cool and convectively mix with the upper, cooler water; and 2) warming air temperatures (daily average air temperatures increased from $1.9^{\circ} \mathrm{C}$ to $3.0^{\circ} \mathrm{C}$ during this period) caused snowmelt at higher elevations in the watershed to activate deep groundwater influx to lower levels of the lake.

The first explanation is rejected because of the rapid increase in water temperature after the 6-day cooling period. It is doubtful that the sediments would become thermally reactivated quickly after being drained. The second explanation is more plausible, as snowmelt activation of groundwater aquifers can be a rapid consequence of increased air temperatures (Fleming, 1966). Since the forest soils of the lower elevations of New Hampshire remain unfrozen during the winter (Likens et al., 1967), snowmelt water quickly percolates to the groundwater table, which is relatively high in the Post Pond watershed. Further geohydrological study of the watershed is needed to support this interpretation. 


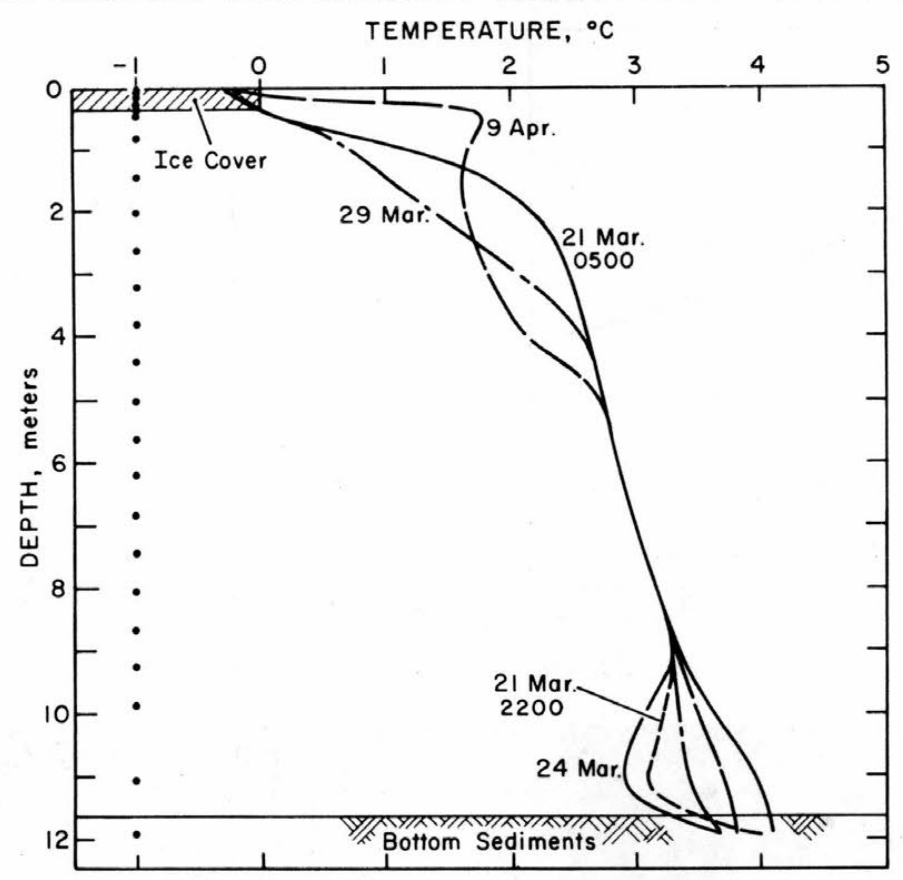

Figure 11. Late winter cooling of bottom water.

Melting of the ice cover - melting process. The melting period lasted from 7 March to 19 April (43 days). Ice generally melts from the top due to the development of a high positive net radiation in the spring (Hutchinson, 1957). Temperature measurements at the ice/water interface combined with ice thickness measurements at Post Pond indicate that the process may be more complex, especially with the added parameter of snowmelt runoff.

The melt season at Post Pond can be conveniently divided into three periods: 1) initial radiation melting of the upper snow-ice from 8 March to 2 April; 2) melting of the clear ice from under the ice cover (2 April to 10 April); and 3) melting of the remainder of the snow-ice from 10 April to 19 April. Initial melting of the snow-ice by radiation began on $8 \mathrm{March}$ and continued slowly until 2 April, melting the upper $5 \mathrm{~cm}$ of the snow-ice.

Snowmelt water began to flow into the lake via Trout Brook and several small ephemeral streams on 26 March. Flooding of the lowlands occurred from 2 April to 10 April, and it was during this peak snowmelt period ( 8 days) that the entire clear ice section of the cover $(42 \mathrm{~cm})$ melted (Fig. 12 shows the growth and melt of clear ice). The significant aspect of this melting phenomenon is that temperature and ice thickness measurements show that it occurred on the underside of the ice and was mainly due to heat supplied by snowmelt water. Temperatures of the influent stream (Trout Brook) averaged $3.3^{\circ} \mathrm{C}$ during this 8-day period. Radiational heating through $15 \mathrm{~cm}$ of snowice was considered small (Lyons and Stoiber, 1959; Thomas, 1963).

The lake began to melt first around the shoreline, creating a moat around the lake that enlarged in width as melt continued (Fig. 13). Snowmelt water, mainly from the east and north sides of the lake, contributed to the enlargement of the moat and supplied heat for melting the clear ice layer at the base of the ice cover. The development of drainage holes, thought by some investigators (Williams, 1968) to be a major cause of spring melt, were not observed on Post Pond. 


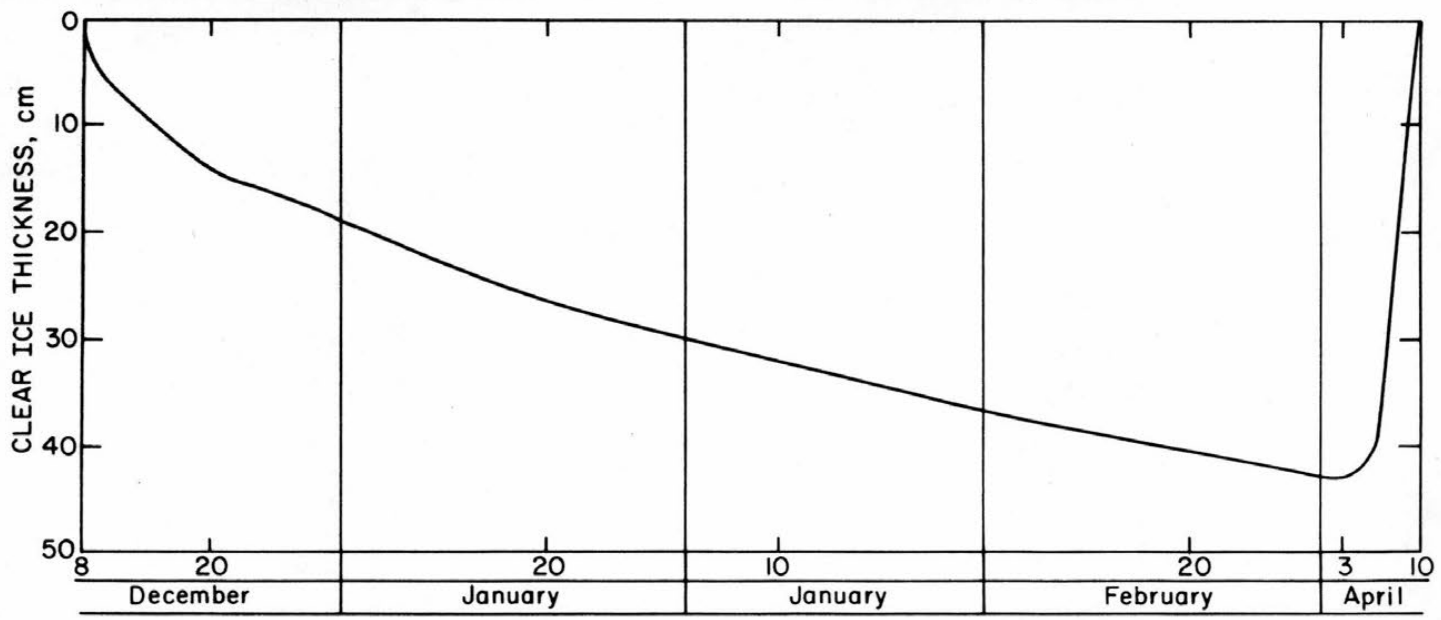

Figure 12. Growth and melt of clear ice.

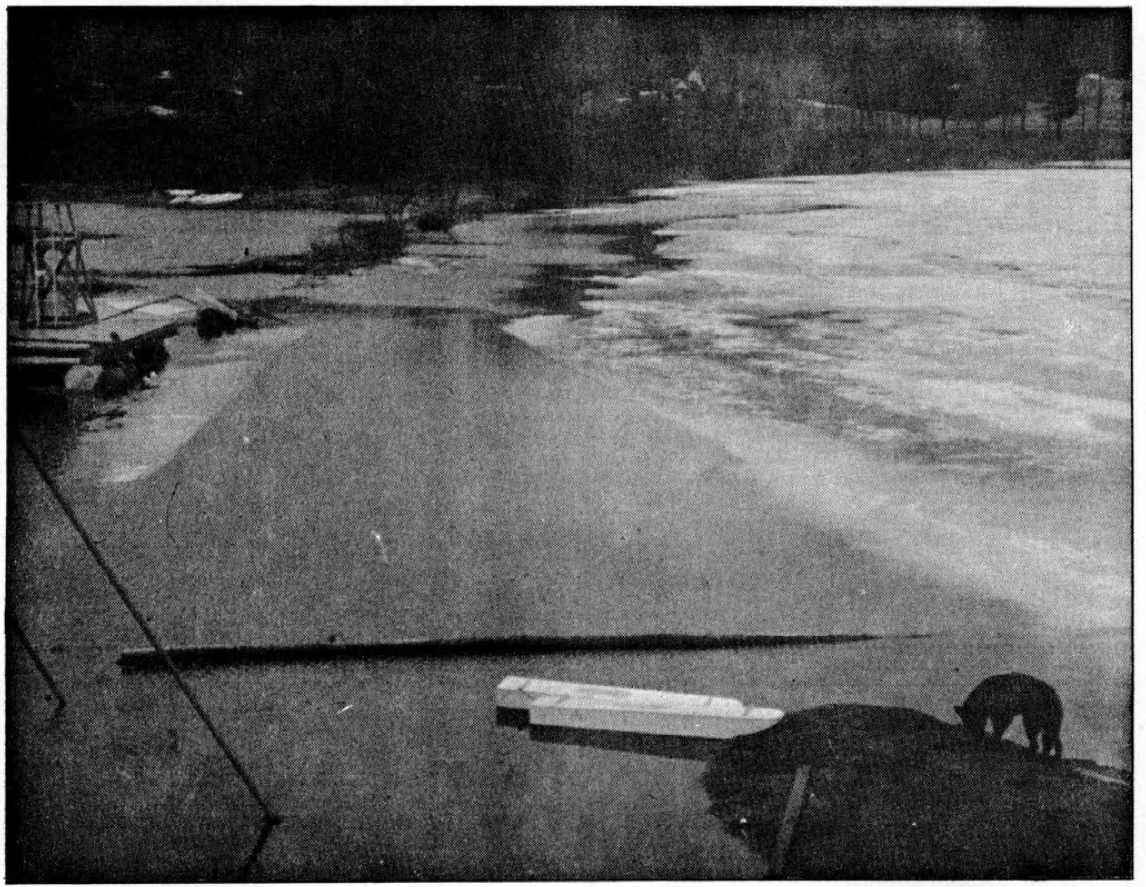

Figure 13. Initial melting and moat formation around shoreline in spring.

The third and final period of melt occurred from 10 April to 19 April and resulted in the complete disappearance of ice from Post Pond. Heat for melting the remaining $15 \mathrm{~cm}$ of snow-ice was supplied by snowmelt water, radiation, and wind mixing. Candling (melting at crystal boundary) of the thin cover observed during this period (Fig. 14) contributed to the disintegration of the cover.

Melting of the ice cover - thermal instability of the water mass during melt season. Thermal instability* of the water mass was observed for 9 days (11-19 April) during the last period of the melt season (Fig. 15). (Thermocouple readings were checked against independent thermistor readings and found to be accurate.) Thermal instability was reported by other investigators (Ruttner, 1952; Bilello, 1968); Ruttner believed it to be a result of chemical strat if ication.

* Thermal instability is defined as a period during which water at either greater or less than $4^{\circ} \mathrm{C}$ underlies water at $4^{\circ} \mathrm{C}$. 


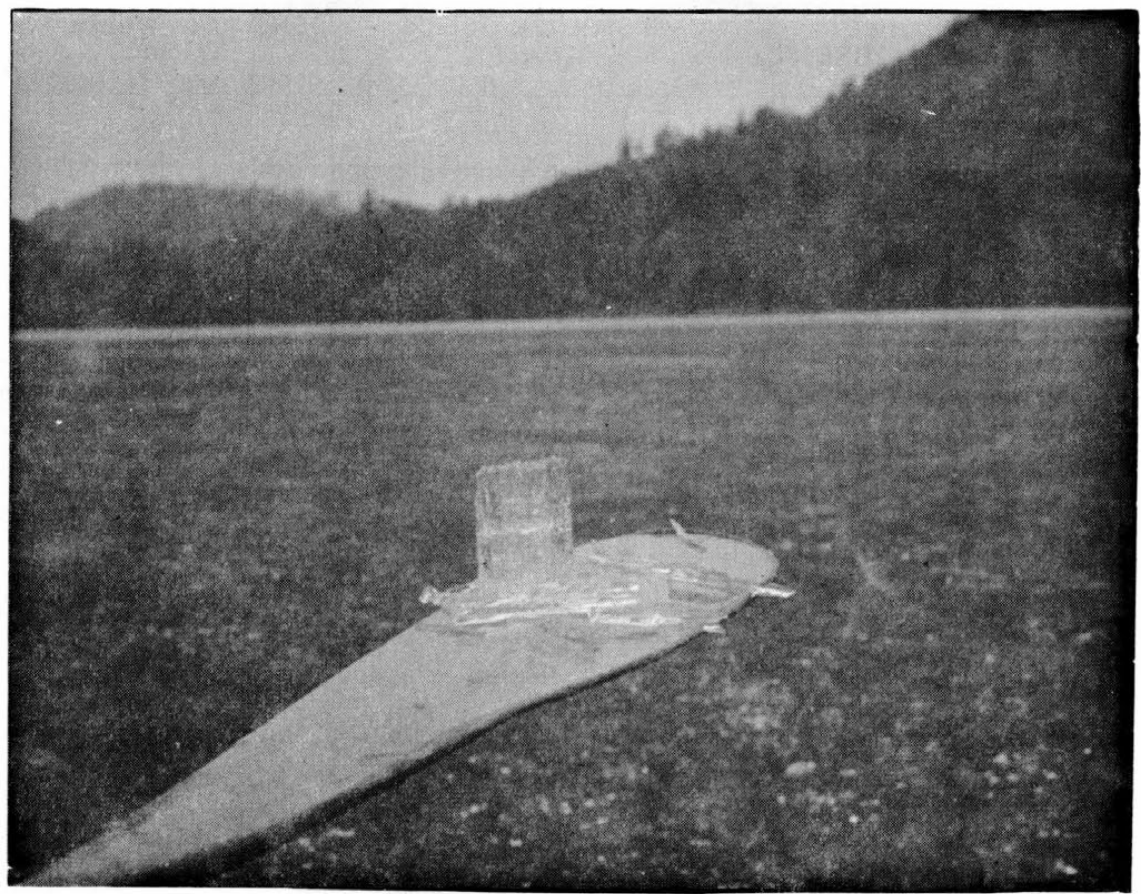

Figure 14. Candling of thin ice cover during spring melting.
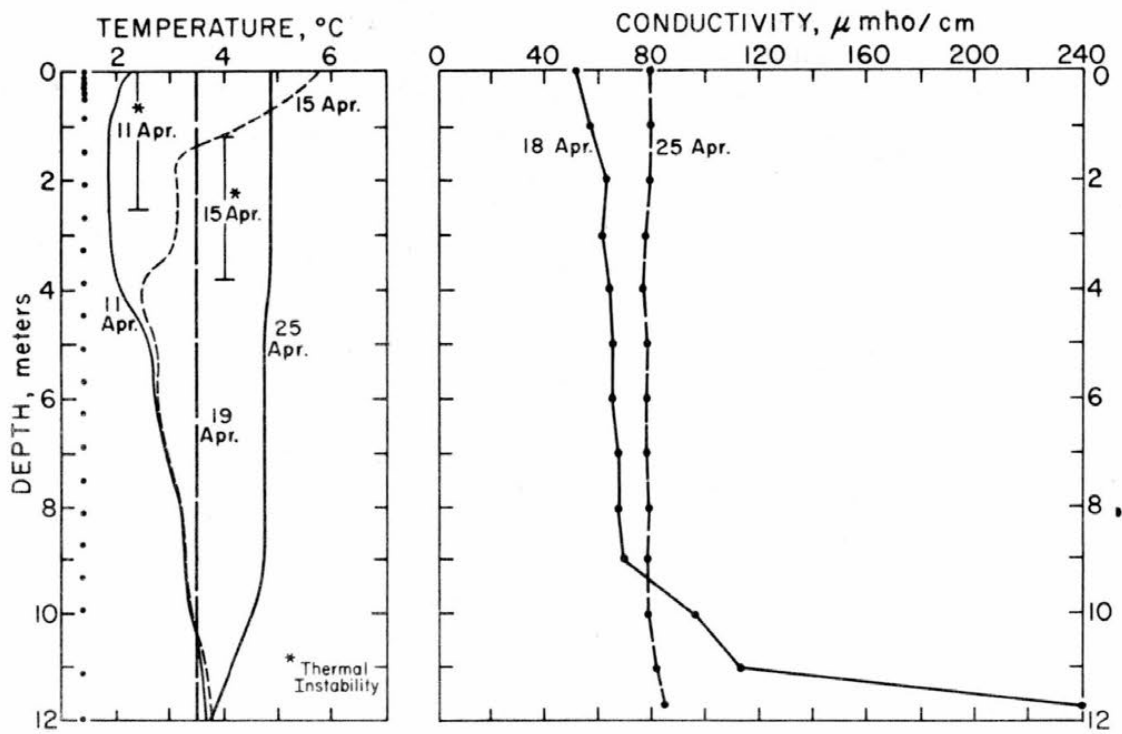

Figure 15. Thermal instability and conductivity during melt season.

Beginning on 11 April the upper $2.5 \mathrm{~m}$ of water was slightly thermally unstable. By 15 April tne upper meter of water had warmed beyond $4{ }^{\circ} \mathrm{C}$ (temperature of maximum density), and water from $1.2 \mathrm{~m}$ to the bottom was thermally unstable. By 19 April the unstable condition ceased and the entire lake was isothermal at $3.5^{\circ} \mathrm{C}$. By $25 \mathrm{April}$ slight stratification began to develop, with the upper 9.5 $\mathrm{m}$ isothermal at $4.9^{\circ} \mathrm{C}$.

During the period of instability, thermal profiles showed significant changes within a few hours. Thermal profiles at 1100 and 1400 on 18 April are shown in Figure 16. Continuous thermal adjustment of the upper $8 \mathrm{~m}$ is evident. Thermal instability occurred from $1.8 \mathrm{~m}$ to the bottom at 1100 hours, but subsequent mixing resulted in a layer of unstable water from 7.5 to $11.0 \mathrm{~m}$ at 1400 hours. 


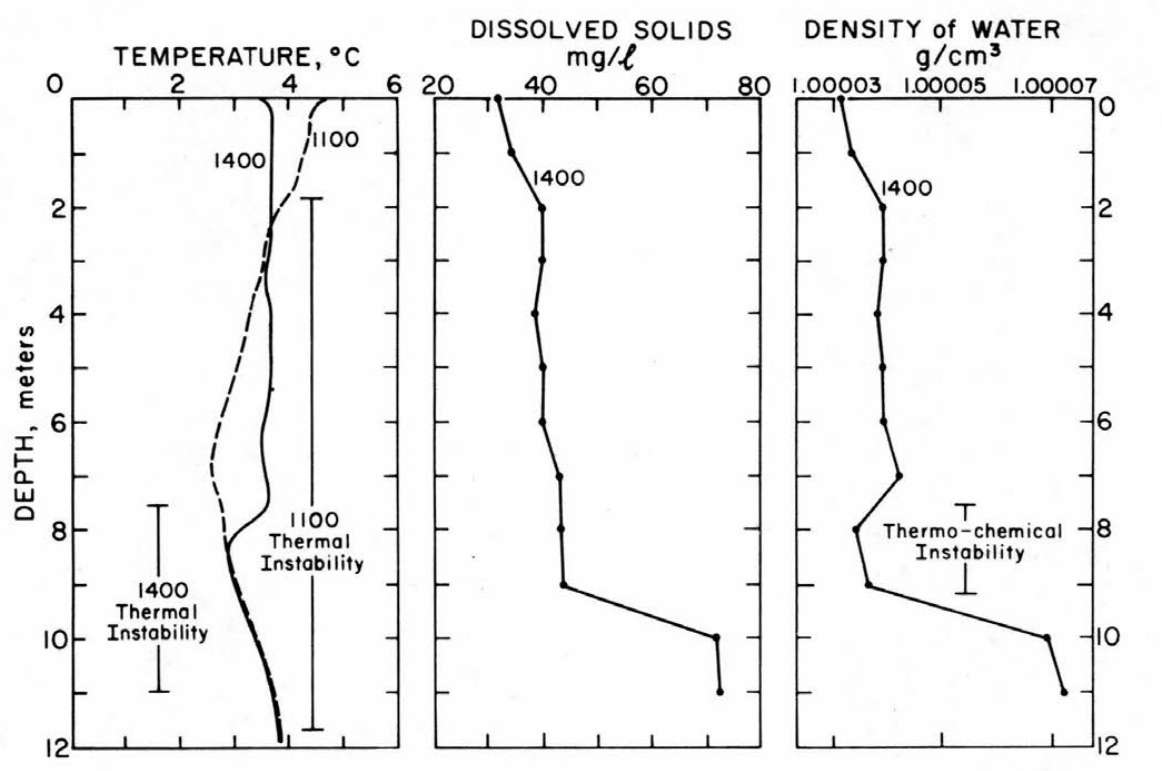

Figure 16. Effect of temperature and dissolved solids on density, 18 April.

Conductivity analyses. The conductivities of water samples collected at 1-m vertical intervals are shown in Figure 15. The water samples were collected with a nonmetallic sample bottle and the conductivities were measured with a Leeds and Northrup conductivity meter. The change in conductivities from a time of thermal instability (18 April) to a time of thermal stability (25 April) is marked, especially in the lower $3 \mathrm{~m}$. On 18 April the upper $2 \mathrm{~m}$ of water had conductivities averaging $10 \mu \mathrm{mhos} / \mathrm{cm}$ less than the underlying $6 \mathrm{~m}$, and the bottom $3 \mathrm{~m}$ of water had conductivities averaging $68 \mu \mathrm{mhos} / \mathrm{cm}$ more than the overlying $7 \mathrm{~m}$, indicating chemical strat if ication. Between 19 and 25 April, when the lake mixed thoroughly, a significant change occurred, and values were essentially the same throughout the depth of the lake. All evidence of instability disappeared and the lake was completely mixed to $10 \mathrm{~m}$.

Dissolved solids analyses. Dissolved solids of water samples collected at $1-\mathrm{m}$ vertical intervals at 1400 hours on 18 April are shown in Figure 16. Analyses included the major cations $(\mathrm{Ca}, \mathrm{Mg}, \mathrm{K}$, and $\mathrm{Na})$; and for this interpretation the sulfate $\left(\mathrm{SO}_{4}\right)$ anion, although not measured on these samples, was assumed to be the major anion. Cation analyses are shown in Table I. This assumption is reasonable consider ing the high sulfate content of New Hampshire waters (Love, 1960). The dissolved solids were strat if ied and increased with depth, showing the greatest increase ( $28 \mathrm{mg} / \mathrm{liter}$ ) between $9 \mathrm{~m}$ and $10 \mathrm{~m}$.

Combined effect of temperature and dissolved solids on density. The density of the water mass calculated from the temperature data at 1400 hours is shown in Figure 16. Overall instability occurred from $7.5 \mathrm{~m}$ to $9.2 \mathrm{~m}$, and can be termed thermo-chemical instability because it combines the effects of temperature and dissolved solids. Water that is apparently $8 \mathrm{mg} / \mathrm{liter}$ lighter than the water above occurs in the unstable layer. It is concluded that while an increase with depth in dissolved solids aids in explaining thermal density instability, it is obviously not the whole explanation.

The period of instability correlates well with the time of peak snowmelt runoff. Particulate matter (suspended solids) deposited by snowmelt waters (not measured in this analysis) may have contributed to further instability especially at lower levels in the lake. 
Table I. Cation analyses, 18 April 1969 (mg/liter)

\begin{tabular}{ccccc} 
Depth $(\mathrm{m})$ & $\mathrm{K}^{+}$ & $\mathrm{Na}^{+}$ & $\mathrm{Mg}^{++}$ & $\mathrm{Ca}^{++}$ \\
\hline Surface & 0.25 & 2.30 & 0.74 & 6.10 \\
1 & 0.30 & 2.55 & 0.77 & 6.40 \\
2 & 0.35 & 3.05 & 0.85 & 7.50 \\
3 & 0.35 & 3.10 & 0.85 & 7.50 \\
4 & 0.35 & 3.05 & 0.88 & 7.10 \\
5 & 0.35 & 3.45 & 0.90 & 7.10 \\
6 & 0.35 & 3.45 & 0.89 & 7.20 \\
7 & 0.35 & 3.85 & 0.93 & 7.60 \\
8 & 0.35 & 4.10 & 0.93 & 7.55 \\
9 & 0.35 & 4.20 & 0.93 & 7.50 \\
10 & 1.00 & 7.60 & 1.18 & 11.85 \\
11 & 1.10 & 9.90 & 1.42 & 9.50 \\
\hline
\end{tabular}

\section{Spring circulation}

Spring overturn. On 19 April three signif icant events occurred: 1) the ice cover completely melted; 2) the thermally unstable profiles of the previous 9 days disappeared; and 3) the spring overturn period began. The beginning of the overturn occurred when the entire lake mixed completely and became isothermal at $3.4^{\circ} \mathrm{C}$ (Fig. 17). The overturn period lasted 4 days, until $23 \mathrm{April}$, when the lake warmed isothermally to $4.5^{\circ} \mathrm{C}$ and then began to stratify.

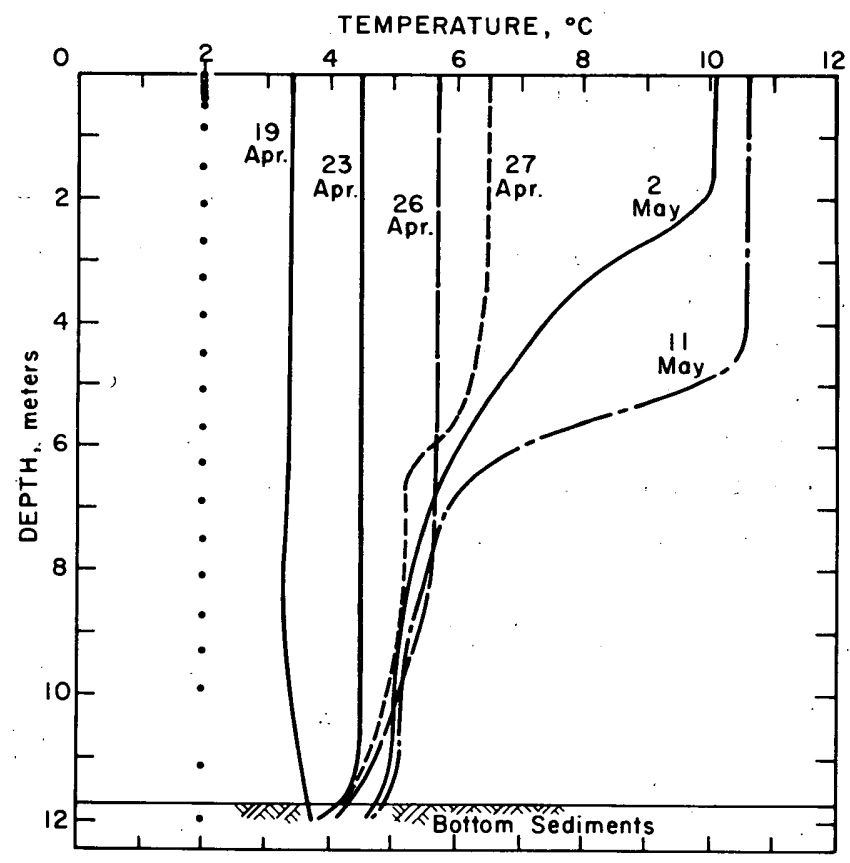

Figure 17. Spring circulation and thermocline development. 
Thermocline development. The mixing process in the spring development of the thermocline was quite different from the mixing process in the autumn when the thermocline was gradually destroyed. As the upper water cooled in the autumn and became more dense, the wind helped to mix it convectively with lighter water beneath. In this case wind and convection worked together to mix the lake. In the spring, however, the convection process and wind were working against each other. As the upper water warmed due to increased air temperatures and radiation, it became less dense and tended to stay on top. Therefore, the only energy available to mix the lake in the spring was wind.

Spring winds mixed the lake to a depth of $8 \mathrm{~m}$ on $26 \mathrm{April}$ and warmed the upper water to $5.7^{\circ} \mathrm{C}$ (Fig. 17). Density differences had become great enough on 27 April so that light winds were able to mix the lake to only $5 \mathrm{~m}$. Due to a relatively windless period of 5 days, mixing occurred to only $2 \mathrm{~m}$ by May. Strong winds then overcame density differences to mix the lake to a depth of $4.5 \mathrm{~m}$ on 11 May, with classical three-layered stratification quite evident (Fig. 17). At this time, density differences had become great enough so that even strong winds were not sufficient to develop the thermocline further. The period of spring circulation was essentially over, and the summer stratification period had begun.

\section{SUMMARY AND CONCLUSIONS}

The data show that Post Pond is a typical dimictic, mid-latitude lake; based on the data, the following statements can be made.

1. Secondary and tertiary thermocline development in the epilimnion occurred during short warming periods in the early autumn. The rate of temperature decrease in the tertiary thermocline $\left(6.0^{\circ} \mathrm{C} / \mathrm{m}\right)$ was more than twice the rate of decrease in the primary thermocline.

2. The autumn overturn lasted 25 days, whereas the spring overturn lasted only 4 days.

3. The entire lake mixed isothermally in the autumn to $3.2^{\circ} \mathrm{C}$, almost one degree lower than the temperature of maximum density.

4. Temperature profiles during the 4 months of ice cover show that the upper $7 \mathrm{~m}$ cooled slightly while the lower $5 \mathrm{~m}$ warmed slightly. The lower $5 \mathrm{~m}$ of water gained approximately 51.5 $\mathrm{cal} / \mathrm{cm}^{2}$ from 10 December to 15 March.

5. The heat flux conducted through the -upper $3 \mathrm{~m}$ of sediments into Post Pond during maximum ice cover was approximately 0.6 cal $/ \mathrm{cm}^{2}$ day, or 56.6 cal $/ \mathrm{cm}^{2}$.from 10 December to $15 \mathrm{March}$. Heat from the bottom sediments is enough to account for the warming of the water mass during the existence of a stable ice cover.

6. A steady-state thermal gradient of $0.07^{\circ} \mathrm{C} / \mathrm{m}$ was found for the deeper $6 \mathrm{~m}$ of the sediments underlying the lake during ice cover. This is approximately three times the normal geothermal gradient of $0.02^{\circ} / \mathrm{m}$ quoted by Van Orstrand (1939). This is also approximately half as much as the thermal gradient of $0.20^{\circ} \mathrm{C} / \mathrm{m}$ measured in a Wiscons in lake (Likens and Johnson, 1969). The thermal conductivity of the sediments was not measured.

7. Late winter cooling of bottom water under the ice cover may be the result of snowmelt in the areas adjacent to the lake-causing activation of groundwater influx to lower levels of the lake.

8. The clear ice portion of the ice cover melted in 8 days; this was caused primarily by heat supplied to the lake by snowmelt water. Melting occurred on the underside of the ice sheet. 
9. Thermal instability of the water mass persisted for 9 days during peak snowmelt runoff; this can be partially explained by an increase in dissolved solids with depth.

\section{LITERATURE CITED}

Anderson, D.V. (1964) The thermal regime of Lake Simcoe. Ontario Department of Lands and Forests, Research Report 57, 14 p.

(1968) Nocturnal heat loss of lake and seasonal variation in its vertical thermal structure. Bulletin, International Association of Scientific Hydrology, vol. 13, no. 3, p. 33-40.

Bilello, M.A. (1968) Water temperatures in a shallow lake during ice formation, growth, and decay. Water Resources Research, vol.4, no. 4, p. 749-760.

Birge, E.A. (1910) On the evidence for temperature seiches. Transactions of the Wisconsin Academy of Scientific Arts and Letters, vol. 16, p. 1005-1016.

(1915) The heat budgets of American and European lakes. Transactions of the Wisconsin Academy of Scientific Arts and Letters, vol.18, p. 166-213.

Dake, J.M.K., and Harleman, D.R.F. (1969) Thermal stratification in lakes: analytical and laboratory studies. Water Resources Research, vol. 5, no. 2, p. 484-495.

Deevey, E.S. (1942) A re-examination of Thoreau's “Walden." Quarterly Review of Biology, vol. 17, p. 1-11.

Dutton, J.A., and Bryson, R.A. (1962) Heat flux in Lake Mendota. Limnology and Oceanography, vol. 7 , no. 1, p. $80-97$.

Edinger, J.E.; Duttweiler, D.W. and Geyer, J.C. (1968) The response of water temperatures to meteorological conditions. Water Resources Research, vol, 4, no. 5, p. 1137-1143.

Environmental Science Services Administration (ESSA) - Weather Bureau (1966) Climatological records.

Fleming, W.M. (1966) Geohydrology of a mountain peat wetland, Medicine Bow Mountains, Wyoming. Colorado Station University, M.S. thesis.

Hem, J.D. (1959) Study and interpretation of the chemical characteristics of natural water. U.S. Geological Survey, Water Súpply Paper 1473.

Hutchinson, G.E. (1937) Limnological studies in Indian Tibet. International Review of Hydrobiology, vol. 35, p. 47-132.

(1957) A treatise on limnology, vol. 1. New York: John Wiley and Sons, Inc.

Johnson, N.M., and Likens, G.E. (1967) Steady-state thermal gradient in the sediments of a micromictic lake. Journal of Geophysical Research, vol. 72, p. 3049-3052.

Langway, C.C. (1958) Ice fabrics and the universal stage. U.S. Army Snow Ice and Permafrost Research Establishment (USA SIPRE), Technical Report 62.

Likens, G.E., and Ragotzkie, R.A. (1965)Vertical water motions in a small ice-covered lake. Journal of Geophysical Research, vol. 70, p. 2333-2344.

Bormann, F.H.; Johns on N.M. and Pierce, R.S. (1967) The calcium, magnesium potassium and sodium budgets for a small forested ecosystem. Ecology, vol. 48, p. 772-785. and Johnson, N.M. (1969) Measurement and analysis of the annual heat budget for the sediments in two Wiscons in Lakes. Limnology and Oceanography, vol. 14, no. 1, p. 115-135.

Love, S.K. (1960) Quality of surface waters of the United States, (1957) Part 1-4, U.S. Geological Survey, Water Supply Paper 1520.

Lyons, J.B., and Stoiber, R.E. (1959) The absorptivity of ice: A critical review. Scientific Report 3, Air Force Cambridge Research Center,

McGaw, R. (in prep) Thermal conductivity of Lake-bottom sediments. U.S. Army Cold Regions Research and Engineering Laboratory (USA CRREL), Special Report 129. 


\section{LITERATURE CITED (Cont'd)}

Ragle, R.H. (1963) Formation of lake ice in a temperate climate. USA CRREL Research Report 107, $22 \mathrm{p}$.

Reid, G.K. (1961) Ecology of inland waters and estuaries. New York: Reinhold Publishing Corporation.

Ruttner, F. (1952) Fundamentals of limnology. Toronto: University of Toronto Press.

Swinzow, G.K. (1966) Ice cover of an Arctic proglacial lake. USA CRREL Research Report 155 (AD 632987).

Takagi, S. (1970) Spline function applied to analyzing lake temperature observations. USA CRREL Technical Note (unpublished).

Thomas, C.W. (1963) On the transfer of visible radiation through sea ice and snow Journal of $\mathrm{s}$ Glaciology, vol. 4, no. 34, p. 481-484.

Trewartha, G.T. (1954) An introduction to climate, 3rd ed. New York: McGraw-Hill Book Co.., Inc.. Van Orstrand, C.E. (1939) Internal constitution of the earth, New York:McGraw-Hill Book Co., Inc.

Williams, G.P. (1968) Freeze-up and break-up of fresh water lakes.: National Research Council, $\cdots$ Canada, Technical Memorandum No. 92, p. 217-229. $\because \ldots$ a

Yen, Y.C., and Galea, F. (1969) Onset of convection in water layer formed continuousl y.by melting ice. Physics of Fluids, vol. 12, no. 3, p. 509-516.

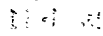

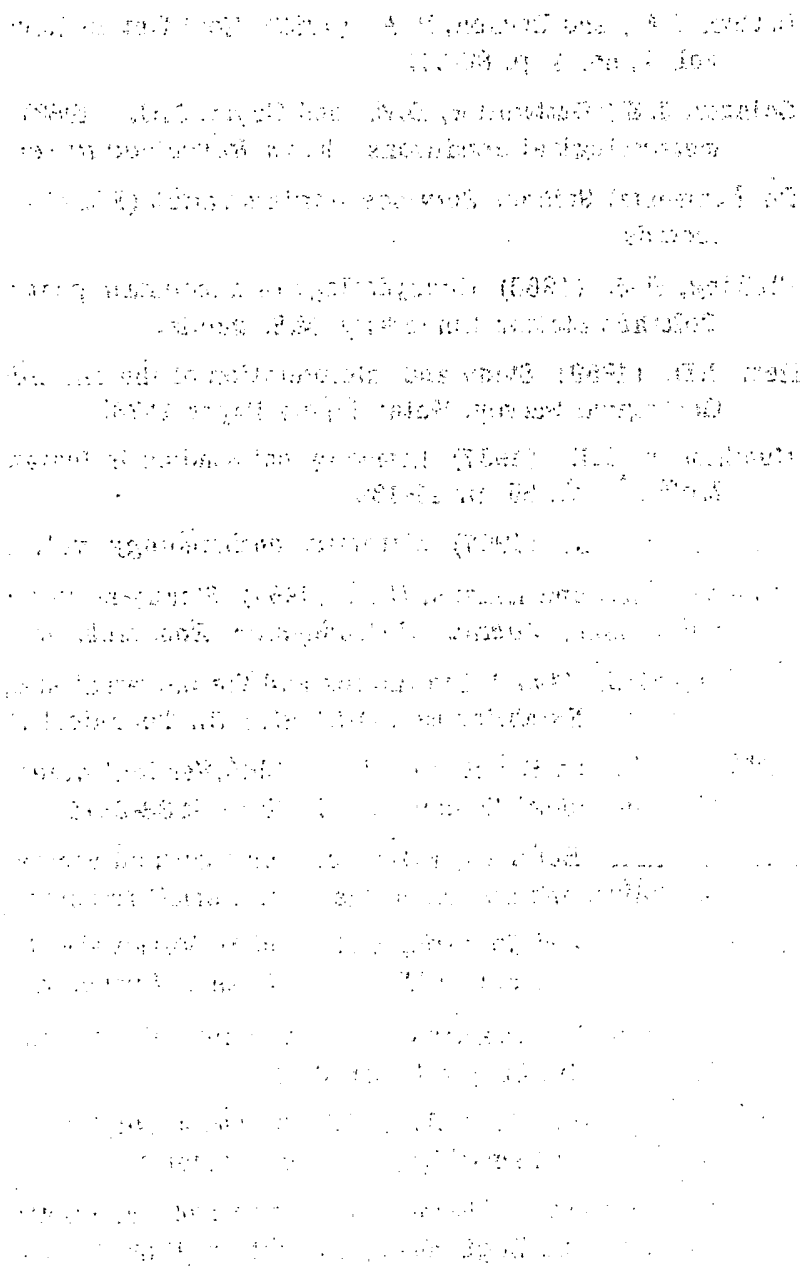


APPENDIX A: ICE SAMPL GS

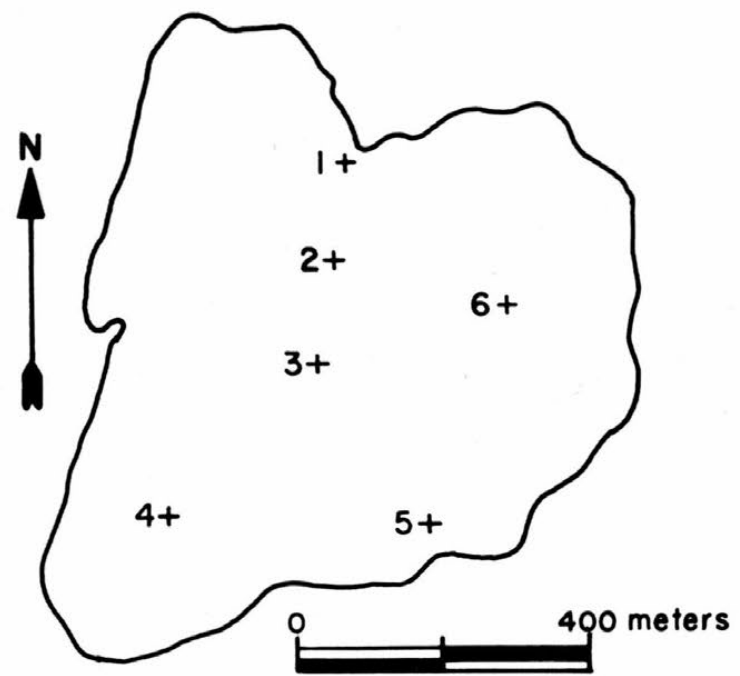

Figure A1. Ice sampling sites.

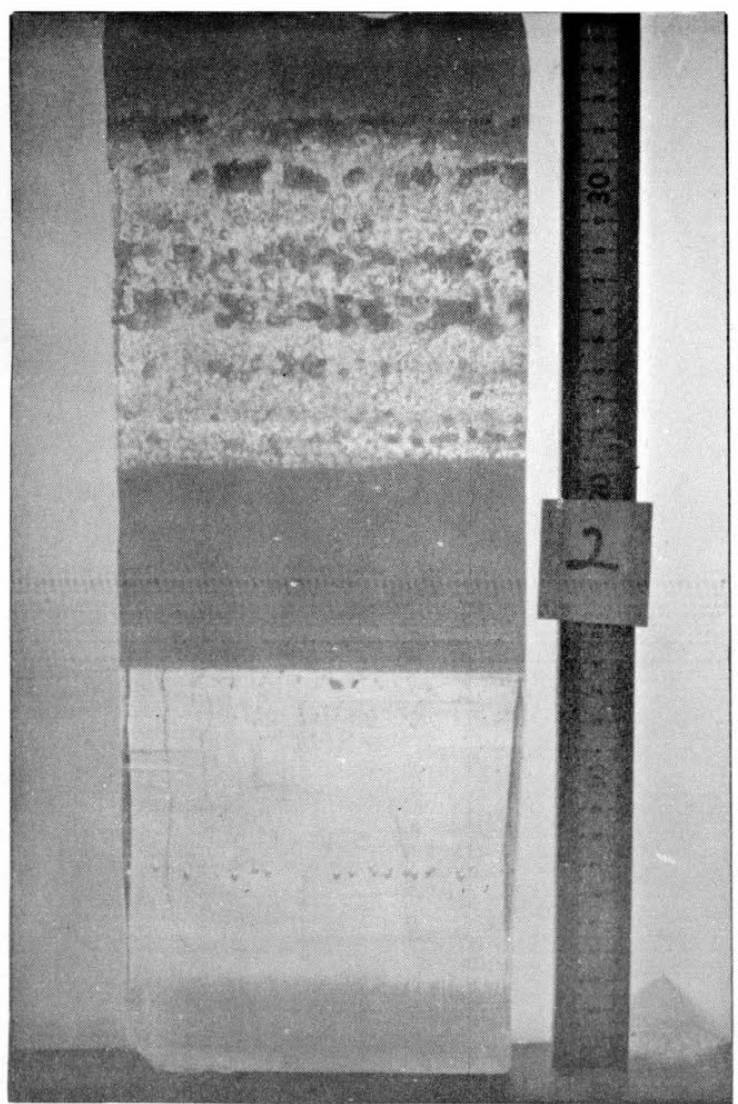

Figure A3. Side view of sample collected from site 2 with approximately $35 \mathrm{~cm}$ of ice: $15 \mathrm{~cm}$ clear ice and $20 \mathrm{~cm}$ snow-ice. The dark band is the original snow-ice and was probably frozen rapidly.

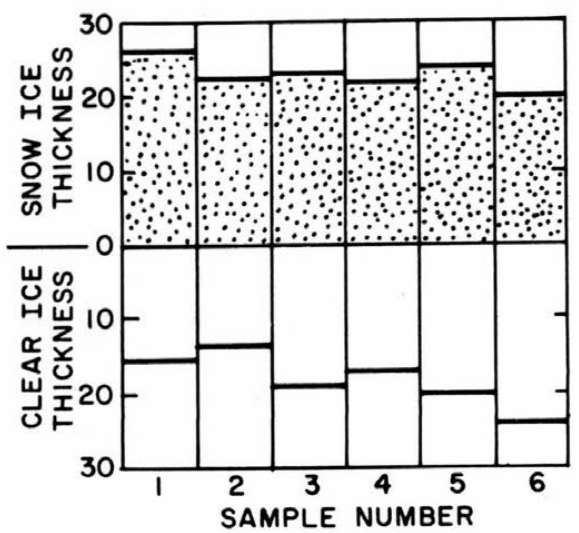

Figure A2. Snow-ice and clear ice growth $(\mathrm{cm})$.

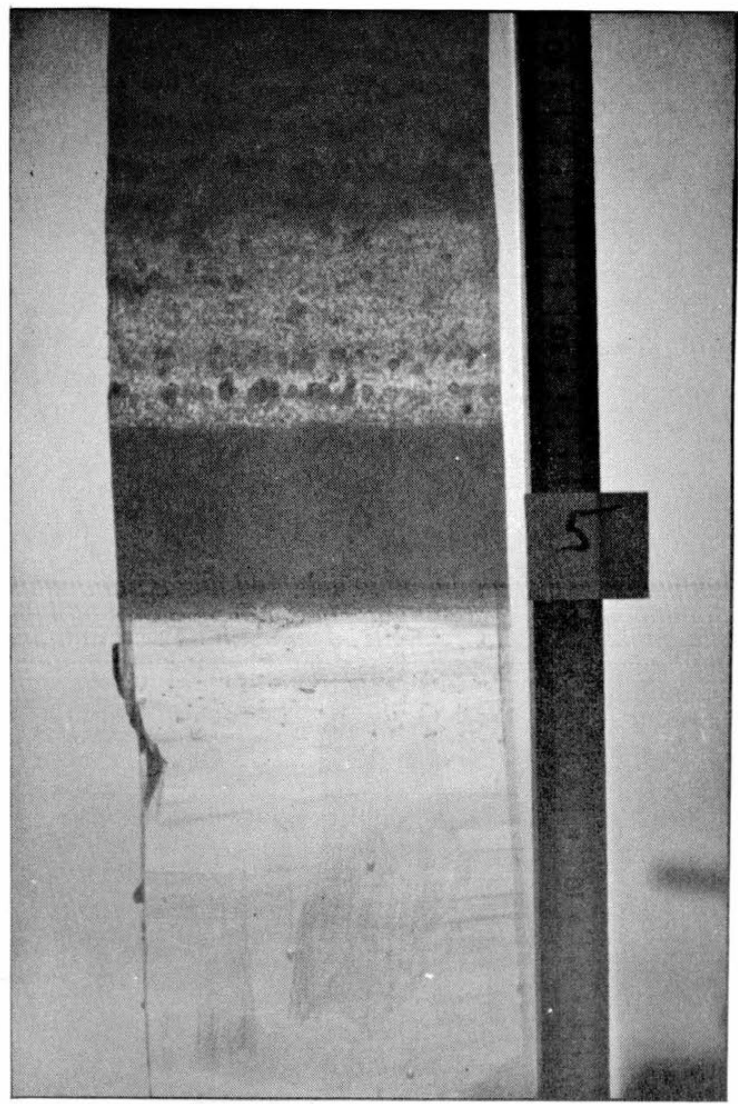

Figure A4. Side view of a sample collected from site 5 with over $40 \mathrm{~cm}$ of ice, $20 \mathrm{~cm}$ of which is clear ice. The difference between this sample and that for site 2 represents the inhomogeneity of ice on a particular body of water. 
DOCUMENT CONTROL DATA - R \& D

(Security classification of title, body of abstract and indexing annotation must be entered when the overall report is classified) \begin{tabular}{l|l} 
1. ORIGINATING ACTIVITY (Corporate author) & 2E. REPORT SECURITY CLASSIFICATION
\end{tabular}

U.S. Army Cold Regions Research

\& Engineering Laboratory

2e. REPORT SECURITY C
UnClassified

Hanover, New Hampshire 03755

3. REPORT TITLE

THE TEMPERATURE STRUCTURE OF A MID-LATITUDE, DIMICTIC LAKE DURING FREEZING, ICE COVER, AND THAWING

4. DESCRIPTIVE NOTES (TyPe of roport and inclusive dates)

5. AUTHOR(S) (First name, middle initial, last name)

W.H. Parrott and Captain W.M. Fleming

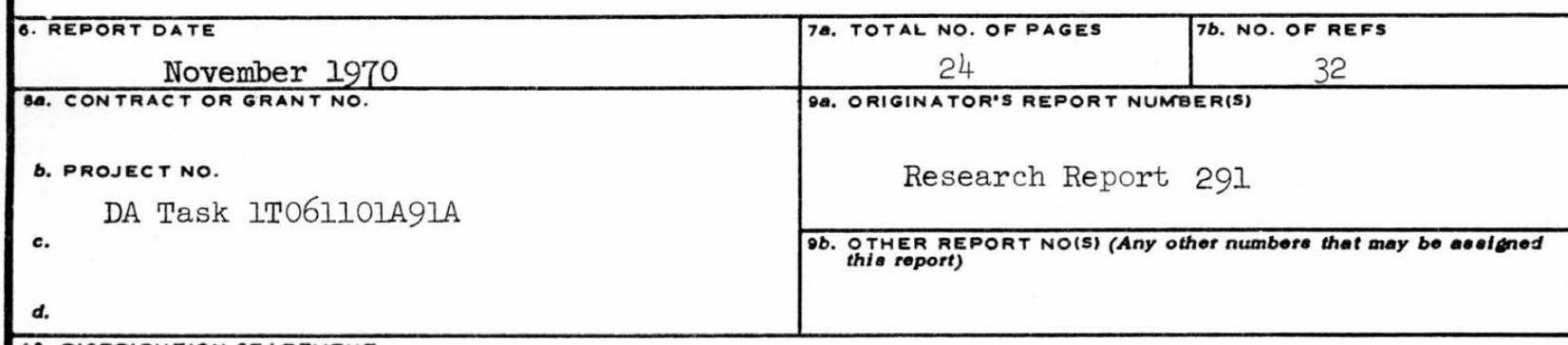

10. DISTRIBUTION STATEMENT

This document has been approved for public release and sale; its distribution is unlimited.

11. SUPPLEMENTARY NOTES

12. SPONSORING MILITARY ACTIVITY
U.S. Army Cold Regions Research
\& Engineering Laboratory
Hanover, New Hampshire 03755

13. ABSTRAC

The temperature structure of Post Pond, a small ( 46.6 hectares), mid-latitude, dimictic lake in west-central New Hampshire, was studied during autumn,winter and spring of 1968-1969. The lake was instrumented over its maximum depth ( $11.7 \mathrm{~m}$ ) with a string of 24 thermocouples which recorded hourly temperatures. Temperatures in $9 \mathrm{~m}$ of sediments underlying the lake were measured with a thermistor probe. Secondary and tertiary thermocline development in the epilimnion occurred during short warming periods in the early autumn. The autumn overturn lasted 25 days, whereas the spring overturn lasted only 4 days. The entire lake mixed isothermally in the autumn to $3.2^{\bullet} \mathrm{C}$. During the period of ice cover, the lower $5 \mathrm{~m}$ of water gained approximately $51.5 \mathrm{cal} / \mathrm{cm}^{2}$, which was supplied by stored heat in the bottom sediments. A steady-state thermal gradient o: $0.07^{\circ} \mathrm{C} / \mathrm{m}$ was found for the deeper sediments underlying the lake during ice cover. Lat• winter cooling of bottom water under the ice cover may be the result of snowmelt in areas adjacent to the lake causing activation of groundwater influx. Melting of the clear ice portion of the ice cover was primarily the result of heat supplied to the lake from snowmelt water, and occurred on the underside of the ice sheet. Thermal instability of the water mass persisted for 9 days during peak snowmelt runoff; this can be partially explained by an increase in dissolved solids with depth.

14. KEY WORDS

Ice formation

Ice breakup
Ice disintegration Freezeup
Limnology 